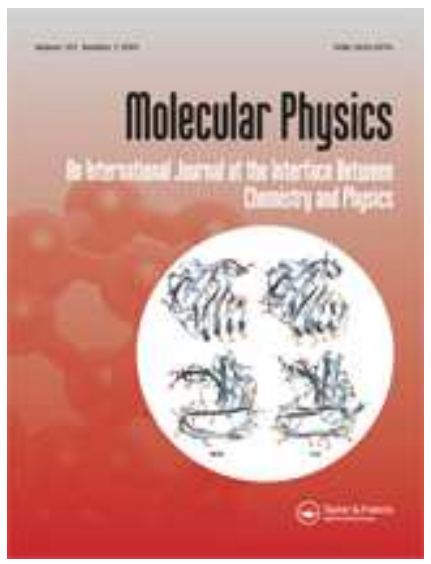

\title{
Effect of pH on superoxide/ hydroperoxyl radical trapping by nitrones: an EPR/kinetic study
}

\begin{tabular}{|r|l|}
\hline Journal: & Molecular Physics \\
\hline Manuscript ID: & TMPH-2007-0078.R1 \\
\hline Manuscript Type: & Full Paper \\
\hline Date Submitted by the \\
Author: & 04-May-2007 \\
\hline Complete List of Authors: & $\begin{array}{l}\text { TUCCIO, Beatrice; Marseille Université } \\
\text { Lauricella, Robert; Marseille Université }\end{array}$ \\
\hline Keywords: & EPR , kinetics, spin trapping, superoxide, nitrones \\
\hline & \\
\hline
\end{tabular}

\section{s scholarONE" \\ Manuscript Central}


Molecular Physics, Vol. X, No. X, Month 2007, xxx-xxx

A. Allouch et al. $\quad$ pH Effect on Superoxide Trapping by Nitrones

\title{
Effect of pH on superoxide/ hydroperoxyl radical
}

\section{trapping by nitrones: an EPR/kinetic study}

\author{
A. ALLOUCH, R. P. LAURICELLA and B. N. TUCCIO* \\ Laboratoire TRACES, Aix-Marseille Universités, case 512, Faculté de St Jérôme, \\ 13397 Marseille cedex 20, France. \\ *Corresponding author. Email: tuccio@up.univ-mrs.fr
}

The $\mathrm{pH}$ dependence of the apparent rate constant $\mathrm{k}_{\text {Tap }}$ for $\mathrm{O}_{2}{ }^{-} / \mathrm{HO}_{2}$ trapping by four nitrones was examined. In each case, kinetic curves were obtained after treatment of EPR spectra of the spin adduct formed using both singular value decomposition and pseudo-inverse deconvolution methods. Modelling these curves led to evaluate $\mathrm{k}_{\text {Tap }}$ at various $\mathrm{pH}$ values. Analysis of the $\mathrm{pH}$ dependence of $\mathrm{k}_{\mathrm{Tap}}$ permitted the determination of the rate constants for the spin trapping of $\mathrm{O}_{2}{ }^{-}$and of $\mathrm{HO}_{2} \cdot$ separately. Whatever the nitrone, our results clearly show that the EPR signals of the nitrone/superoxide spin adducts observed in aqueous media were essentially due to the trapping of the protonated species $\mathrm{HO}_{2}$

Keywords: EPR; Kinetics; pH Effect; Spin Trapping; Superoxide; Nitrones 


\section{Introduction}

Since the EPR/spin trapping technique was first introduced [1-3], it has found numerous applications in the detection of free radicals produced in chemistry, biology or medicine. It has been notably employed for detecting superoxide in aqueous media using nitrone spin traps [4-6]. For this purpose, a nitrone must trap rapidly this radical and must lead to a long-lived spin adduct. Several reliable methods have been described to determine $\mathrm{k}_{\mathrm{D}}$, the rate constant for the nitrone/superoxide spin adduct decay [7-13]. In contrast, evaluating the apparent rate of superoxide trapping by a nitrone, $\mathrm{k}_{\mathrm{Tap}}$, is more problematic and major disagreements exist regarding the data published in this field [11,14-21]. The most popular method used in these studies involves a competition between the nitrone and a superoxide scavenger, and implies that the superoxide spontaneous dismutation, the spin adduct decay and the consumption of the competitor during the course of the experiment correspond to negligible events [11,14-17]. Two years ago, we brought evidences of the importance of these three reactions and showed that their omission resulted in significantly overestimating $\mathrm{k}_{\text {Tap }}$ [22]. Another method based on a competition between the superoxide trapping by the nitrone and the spontaneous dismutation of this radical yielded lower $\mathrm{k}_{\text {Tap }}$ values []18,19]. This prompted us to elaborate a new kinetic approach to the evaluation of $\mathrm{k}_{\mathrm{Tap}}$ in buffered media [20,21]. It was also based on a competition between the superoxide trapping and its spontaneous dismutation, and kinetic curves were obtained after treatment of EPR spectra using both singular value decomposition (SVD) and pseudo-inverse deconvolution methods before their computer modelling. Whatever the method used, it is widely admitted that the kinetic parameters related to the spin trapping of superoxide by nitrones are $\mathrm{pH}$ dependent. On one hand, nitrone/superoxide spin adducts decayed 
more slowly in acidic media [7-9]. On the other hand, $\mathrm{k}_{\text {Tap }}$ also greatly varied with $\mathrm{pH}$ $[14,16]$, owing to the fact that superoxide $\mathrm{O}_{2}{ }^{-}$and its protonated form $\mathrm{HO}_{2}{ }^{-}$were not distinguished in these studies, both radicals leading to the same EPR-detectable spin adduct in aqueous media. The relative concentrations of $\mathrm{HO}_{2}$ and of $\mathrm{O}_{2}^{-}$depend on $\mathrm{pH}$, the $\mathrm{pK}_{\mathrm{A}}$ value for the acidic dissociation reaction of the hydroperoxyl radical being equal to 4.88 [23]. Considering that nitrones react differently with $\mathrm{HO}_{2}{ }^{\cdot}$ and $\mathrm{O}_{2}{ }^{-}$, this justifies the $\mathrm{pH}$ dependence of $\mathrm{k}_{\mathrm{Tap}}$.

Recently, we have found that three nitrones were particularly efficient for superoxide detection: the ethyl 2-methyl-3,4-dihydro-2H-pyrrole-carboxylate 1-oxide 1 (EMPO, $\mathrm{k}_{\mathrm{Ta}} \approx 11 \mathrm{dm}^{3} \mathrm{~mol}^{-1} \mathrm{~s}^{-1}$ at $\mathrm{pH}$ 7.2), the diethyl 3,4-dihydro-2H-pyrrole-2,2-dicarboxylate 1-oxide 2 (DEPO, $\mathrm{k}_{\mathrm{Tap}} \approx 31 \mathrm{dm}^{3} \mathrm{~mol}^{-1} \mathrm{~s}^{-1}$ at $\mathrm{pH}$ 7.2), and 1,3,5-tri [(N- (1diethylphosphono)-1-methyl-ethyl) - $N$-oxy-aldimine] benzene 3 (TN, $\mathrm{k}_{\mathrm{Tap}} \approx 9 \mathrm{dm}^{3} \mathrm{~mol}^{-}$ ${ }^{1} \mathrm{~s}^{-1}$ at $\mathrm{pH}$ 7.2) [20,21]. Among them, $\mathrm{TN}$ is the only lipophilic trap, with an octanol/water partition coefficient higher than 300 [24]. By far, DEPO was found the fastest at trapping superoxide, but the spin adduct thus formed decayed very rapidly, particularly when high nitrone concentrations were used. However, kinetic experiments with all these traps were only performed at $\mathrm{pH}$ 7.2. To proceed with this study, we have examined the $\mathrm{pH}$ dependence of the rate constant for the superoxide trapping by EMPO, DEPO, TN and have compared the results obtained to that given by the well-known 2,2dimethyl-3,4-dihydro-2H-pyrrole 1-oxide 4 (DMPO) (see figure 1). Analysis of the data obtained at various $\mathrm{pH}$ permitted to evaluate separately the rate constant for the trapping of $\mathrm{HO}_{2} \cdot$ and $\mathrm{O}_{2}^{-}$by the nitrone considered and to determine which species is actually responsible for the formation of the adduct detected by EPR.

[Insert figure 1 about here] 
In this whole study, the spin adduct detected by EPR after trapping either $\mathrm{O}_{2}{ }^{-}$or $\mathrm{HO}_{2}{ }^{*}$ with a nitrone $\mathrm{N}$ in aqueous media will be denoted $\mathrm{N}-\mathrm{O}_{2} \mathrm{H}$. With the aim of simplifying the notation, the term 'superoxide' will first be used to designate both superoxide and hydroperoxyl radicals as a whole in the part of this work devoted to the study of the $\mathrm{pH}$ effect on $\mathrm{k}_{\text {Tap. }}$. Similarly, the symbol ' $\mathrm{O}_{2}^{-\cdot}$ ' in the kinetic model [equations (1)-(4)] as well as in the rate equations (5)-(8) will represent either protonated or non-protonated forms of the radical. In a second part of this study, the two species will be considered separately to evaluate each individual contribution to the formation of $\mathrm{N}-\mathrm{O}_{2} \mathrm{H}$.

\section{Experimentals}

\subsection{Materials}

The nitrones EMPO 1, DEPO 2 and TN 3 were synthesised and purified according to procedures described previously [24-27]. DMPO 4 (Sigma-Aldrich Co.) was purified by vacuum distillation before use. Diethylenetriaminepentacetic acid (DTPA), 3-carboxy2,2,5,5-tetramethylpyrrolidin-1-oxyl 5 (3CP), xanthine and xanthine oxidase were obtained from Sigma-Aldrich Co. Buffer solutions, were stirred gently for six hours in the presence of a chelating iminodiacetic acid resin to remove trace metal impurities.

\subsection{Achievement of experimental kinetic curves}

All experiments were made in $0.1 \mathrm{~mol} \mathrm{dm}^{-3}$ phosphate buffer (pH range: 6.2-9.3). Superoxide was produced using a xanthine-xanthine oxidase system. In a standard experiment, the medium contained a nitrone $\mathrm{N}\left(3-200 \mathrm{mmol} . \mathrm{dm}^{-3}\right), 1.6 \mathrm{mmol} . \mathrm{dm}^{-3}$ xanthine, 3 mmol. $\mathrm{dm}^{-3}$ diethylenetriaminepentacetic acid, $3 \mathrm{CP}\left(0.5-1.1 \mu \mathrm{mol} \mathrm{dm}{ }^{-3}\right)$ used as internal standard, and 0.04 unit. $\mathrm{cm}^{-3}$ xanthine oxidase. Air was bubbled into the 


\subsection{Determination of the apparent rate constant $\boldsymbol{k}_{\text {Tap }}$}

At a given $\mathrm{pH}$, the kinetic model considered can be described by equations (1)-(4),

$$
\begin{aligned}
& \mathrm{X} \stackrel{\mathrm{k}_{\mathrm{X}}}{\longrightarrow} \mathrm{O}_{2}{ }^{-} \\
& 2 \mathrm{O}_{2}^{-\cdot}+2 \mathrm{H}^{+} \stackrel{\mathrm{k}_{\mathrm{dis}}}{\longrightarrow} \mathrm{O}_{2}+\mathrm{H}_{2} \mathrm{O}_{2} \\
& \mathrm{O}_{2}{ }^{-\cdot}+\mathrm{H}^{+}+\mathrm{N} \stackrel{\mathrm{k}_{\text {Tap }}}{\longrightarrow} \mathrm{N}-\mathrm{O}_{2} \mathrm{H} \\
& \mathrm{N}-\mathrm{O}_{2} \mathrm{H} \stackrel{\mathrm{k}_{\mathrm{D}}}{\longrightarrow} \mathrm{Y}
\end{aligned}
$$


where $k_{X}$ and $k_{D}$ are the rate constants for the generation of superoxide and for the decay of the spin adduct $\mathrm{N}-\mathrm{O}_{2} \mathrm{H}$, respectively, $\mathrm{Y}$ representing EPR silent products and $\mathrm{X}$ an intermediate derived from xanthine [20]. The apparent rate constant for the secondorder trapping reaction is denoted $\mathrm{k}_{\mathrm{Tap}}$. The rate equations (5)-(8) can be written from this kinetic model:

$$
\begin{aligned}
& \mathrm{d}[\mathrm{X}] / \mathrm{dt}=-\mathrm{k}_{\mathrm{X}}[\mathrm{X}] \\
& \mathrm{d}\left[\mathrm{O}_{2}^{-{ }^{-}}\right] / \mathrm{dt}=\mathrm{k}_{\mathrm{X}}[\mathrm{X}]-\mathrm{k}_{\mathrm{Tap}}[\mathrm{N}]\left[\mathrm{O}_{2}^{-{ }^{-}}\right]-2 \mathrm{k}_{\mathrm{dis}}\left[\mathrm{O}_{2}^{-\cdot}\right]^{2} \\
& \mathrm{~d}\left[\mathrm{~N}-\mathrm{O}_{2} \mathrm{H}\right] / \mathrm{dt}=\mathrm{k}_{\text {Tap }}[\mathrm{N}]\left[\mathrm{O}_{2}^{-\cdot}\right]-\mathrm{k}_{\mathrm{D}}\left[\mathrm{N}-\mathrm{O}_{2} \mathrm{H}\right] \\
& \mathrm{d}[\mathrm{N}] / \mathrm{dt}=-\mathrm{k}_{\text {Tap }}[\mathrm{N}]\left[\mathrm{O}_{2}^{-\cdot}\right]
\end{aligned}
$$

The term 'superoxide' and the symbol ' $\mathrm{O}_{2}^{-}$', designate here the protonated and nonprotonated forms of the radical indiscriminately. The apparent rate constant for the trapping reaction by the nitrone $\mathrm{N}, \mathrm{k}_{\text {Tap }}$, is $\mathrm{pH}$ dependent and includes the contribution of both $\mathrm{HO}_{2}$ and $\mathrm{O}_{2}^{-}$trapping. The second order rate constant for the superoxide spontaneous dismutation reaction, $\mathrm{k}_{\mathrm{dis}}$, is also $\mathrm{pH}$-dependent. Computer modelling of the kinetic curves obtained was achieved using a home-made programme and according to equations (5)-(8). In these calculations, the nitrone initial concentration is an experimental parameter, the initial concentrations of superoxide and of $\mathrm{N}-\mathrm{O}_{2} \mathrm{H}$ are equal to zero, and $\mathrm{k}_{\mathrm{dis}}$ was evaluated as described further. The standard least-square method was applied to fit the experimental curves, yielding the other parameters. Therefore, the three kinetic curves obtained at three different nitrone concentrations were considered jointly and modelled with the same parameter set (except for parameters varying with the nitrone concentration). The values obtained for the initial concentration $[\mathrm{X}]_{0}$ and for the rate constant $\mathrm{k}_{\mathrm{X}}$ had no real meaning and only came up as an empirical model of the superoxide generation. Since they may vary with the solutions of either xanthine or 
xanthine oxidase used [20], experiments at various nitrone concentrations were performed with exactly the same superoxide generator. The model corresponding to equations (9)-(12), which was first established by Baxendale [29], describes the superoxide spontaneous dismutation in aqueous media. Here, reaction (12) is negligible below pH 9.5 .

$$
\begin{aligned}
& \mathrm{HO}_{2} \stackrel{\mathrm{K}_{\mathrm{A}}}{\longrightarrow} \mathrm{O}_{2}^{-\cdot}+\mathrm{H}^{+} \\
& 2 \mathrm{HO}_{2} \stackrel{\mathrm{k}_{1}}{\longrightarrow} \mathrm{H}_{2} \mathrm{O}_{2}+\mathrm{O}_{2} \\
& \mathrm{O}_{2}^{-\cdot}+\mathrm{HO}_{2} \stackrel{\mathrm{k}_{2}}{\longrightarrow} \mathrm{H}_{2} \mathrm{O}_{2}+\mathrm{O}_{2}+\mathrm{HO}^{-} \\
& 2 \mathrm{O}_{2}^{-\cdot} \stackrel{\mathrm{k}_{3}}{\longrightarrow} \mathrm{H}_{2} \mathrm{O}_{2}+\mathrm{O}_{2}+2 \mathrm{HO}^{-}
\end{aligned}
$$

The rate constant $\mathrm{k}_{\mathrm{dis}}$ can be determined at any $\mathrm{pH}$ from equations (13)-(14), where $\mathrm{pK}_{\mathrm{A}}, \mathrm{k}_{1}$ and $\mathrm{k}_{2}$ are equal to $4.88,7610^{4} \mathrm{dm}^{3} \cdot \mathrm{mol}^{-1} \cdot \mathrm{s}^{-1}$ and $8510^{6} \mathrm{dm}^{3} \cdot \mathrm{mol}^{-1} \cdot \mathrm{s}^{-1}$, respectively [23].

$$
\begin{aligned}
& \mathrm{k}_{\mathrm{dis}}=\left(\mathrm{k}_{1}+\chi \mathrm{k}_{2}\right) /(1+\chi)^{2} \\
& \chi=\mathrm{K}_{\mathrm{A}} /\left[\mathrm{H}^{+}\right]=10^{\left(\mathrm{pH}^{\mathrm{pK}} \mathrm{A}\right)}
\end{aligned}
$$

\subsection{Determination of the trapping rate constants $k_{\mathrm{HO}_{2} \cdot}$ and $\mathrm{k}_{\mathrm{O}_{2}-}$.}

Because nitrones react differently with $\mathrm{O}_{2}^{-}$and with $\mathrm{HO}_{2}$, reactions (15) and (16)

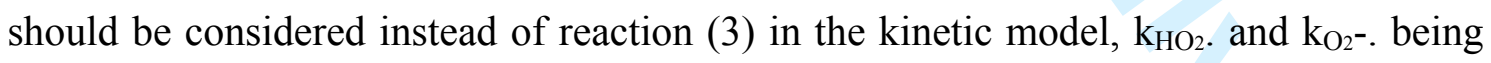
the rate constants for the trapping of superoxide radical anion $\left(\mathrm{O}_{2}^{-}\right)$and hydroperoxyl radical $\left(\mathrm{HO}_{2}{ }^{\circ}\right)$, respectively, by the nitrone $\mathrm{N}$.

$$
\begin{aligned}
& \mathrm{O}_{2}^{-\cdot}+\mathrm{N}+\mathrm{H}^{+} \stackrel{\mathrm{k}_{\mathrm{O}^{-} \cdot} .}{\longrightarrow} \mathrm{N}-\mathrm{O}_{2} \mathrm{H} \\
& \mathrm{HO}_{2} \cdot+\mathrm{N} \stackrel{\mathrm{k}_{\mathrm{HO} 2 \cdot}}{\longrightarrow} \mathrm{N}-\mathrm{O}_{2} \mathrm{H}
\end{aligned}
$$


According to Finkelstein et al. [14], equation. (17) can be written from equations (14)(16).

$$
\mathrm{k}_{\mathrm{Tap}}=\left(\mathrm{k}_{\mathrm{HO} 2 \cdot}+\chi \mathrm{k}_{\mathrm{O} 2 \cdot}-\right) /(1+\chi)
$$

Using the method described in the previous section, $\mathrm{k}_{\text {Tap }}$ was determined for each nitrone at five $\mathrm{pH}$ values ranging from 6.2 to 9.3 . The experimental curves thus obtained were modelled using equation (17), which led to $\mathrm{k}_{\mathrm{HO}_{2}}$. and $\mathrm{k}_{\mathrm{O}_{2} \cdot-\text {. }}$

\section{Results and discussion}

\subsection{Determination of the rate constants at various $\mathrm{pH}$}

Experiments were performed in order to evaluate the $\mathrm{pH}$ influence on the trapping of superoxide by four nitrones: EMPO 1, DEPO 2, TN 3 and DMPO 4. Whatever the species trapped by the nitrone $\mathrm{N}\left(\mathrm{O}_{2}^{-}\right.$or $\mathrm{HO}_{2}{ }^{-}$, both designated here by the term 'superoxide'), only the protonated adduct $\mathrm{N}-\mathrm{O}_{2} \mathrm{H}$ will be detected by EPR. Actually, the anionic radical species $\mathrm{N}_{-} \mathrm{O}_{2}^{-}$is not EPR silent, but its concentration in the $\mathrm{pH}$ range considered is negligible, considering the high $\mathrm{pKa}$ values of hydroperoxides.

The formulae of the stable nitroxide 5 and of the spin adducts 6-9 considered in this study have been drawn in figure 2. Before each kinetic experiment, a full EPR spectrum of the medium was recorded. All the spectra thus obtained were analysed using the computer program elaborated by Duling [30], which led to the values listed in table 1 for the hyperfine splitting constants (hfscs) with the nitrogen $\left(\mathrm{a}_{\mathrm{N}}\right)$, the $\beta$-hydrogen $\left(a_{H \beta}\right)$ and eventually a $\gamma$-hydrogen $\left(a_{H \gamma}\right)$ or a $\beta$-phosphorus $\left(a_{P}\right)$ nuclei. These hfscs were not found to vary in the $\mathrm{pH}$ range considered and agree with the literature data $[4,10,24,27]$. In a previous study [24], we have shown that 
the mono-nitroxide 8 (i.e. the mono-adduct) was almost exclusively formed at the tri-nitrone TN 3 concentrations used, the proportion of bi-nitroxide being negligible. [Insert figure 2 and table 1 about here]

The kinetic approach used, based on a competition between the superoxide trapping and its spontaneous dismutation at a given $\mathrm{pH}$ value, permits the consideration of the whole kinetic curve of superoxide adduct formation and decay. This method has been extensively described elsewhere and will only be briefly explained here [20]. For each nitrone $\mathrm{N}$ considered and at each $\mathrm{pH}$ value studied, a part of the EPR spectrum of $\mathrm{N}-\mathrm{O}_{2} \mathrm{H}$ was recorded as a function of time at various nitrone concentrations, in the presence of an internal reference (see experimental section). In order to illustrate the method employed, an EPR spectrum of the adduct $\mathrm{TN}-\mathrm{O}_{2} \mathrm{H} 8$ recorded at $\mathrm{pH} 6.2$ in the presence of the internal standard $3 \mathrm{CP}$ is shown in figure 3 , the framed part corresponding to the signal range chosen to perform the kinetic experiments. Using both singular value decomposition and pseudo-inverse deconvolution methods, kinetic curves indicating the time dependant changes in the $\mathrm{N}-\mathrm{O}_{2} \mathrm{H}$ concentration at various $\mathrm{pH}$ were achieved. As an example, the curves obtained with the spin trap 3 at $\mathrm{pH} 6.2$ and at $\mathrm{pH} 9.3$ are given in figure 4 . Using equations. (5)-(8), computer modelling of the experimental kinetic curves obtained with each nitrone at each $\mathrm{pH}$ considered yielded the values of $\mathrm{k}_{\mathrm{D}}$ and $\mathrm{k}_{\text {Tap }}$ listed in table 2 .

\section{[Insert figures 3 and 4 and table 2 about here]}

It has been shown that the rate constant for the first-order decay of nitrone/superoxide spin adducts increased with $\mathrm{pH}$ and with the spin trap concentration [7-9,20,21,30]. Overall, the values listed for $\mathrm{k}_{\mathrm{D}}$ in table 2 agree with 
these observations, though a few deviations from this general trend can be noticed. These could be explained by considering two main factors. Firstly, EPR signals recorded under certain extreme conditions (e.g. at high $\mathrm{pH}$ values) were often very weak. Actually, it would have been impossible to achieve the kinetic curves from these spectra without the help of SVD and deconvolution methods. In this case, $\mathrm{k}_{\mathrm{D}}$ determination could be less accurate, as shown for instance by the errors given in table 2. Secondly, the first-order decay of nitrone/superoxide spin adducts in aqueous media are known to depend on several parameters other than $\mathrm{pH}$ and nitrone concentration. In particular, minor changes in the superoxide generator (i.e. in solutions of xanthine or of xanthine oxidase) may affect significantly $\mathrm{N}-\mathrm{O}_{2} \mathrm{H}$ lifetime $[8,10,20,21]$. Considering the number of experiments performed in this study, different solutions of xanthine and of xanthine oxidase have been used, thereby rending $\mathrm{k}_{\mathrm{D}}$ evaluation less accurate. The dependence of the decay rate of nitrone/superoxide adducts on various parameters ( $\mathrm{pH}$, nitrone concentration, superoxide generating system, etc.) is certainly an interesting problem that would warrant a more thorough study. A better knowledge of the mechanisms responsible for $\mathrm{N}-\mathrm{O}_{2} \mathrm{H}$ decay in aqueous solutions would permit the design of new spin traps with increased superoxide adduct life-time. However, the purpose of the present work was mainly to scrutinise the effect of $\mathrm{pH}$ on the superoxide trapping rate. Note that the three series of spectra at the three different nitrone concentrations, for each nitrone and at each $\mathrm{pH}$, were recorded under exactly the same conditions. Thus, in the kinetic approach used, minor changes in the superoxide generator would not affect $\mathrm{k}_{\mathrm{T} a p}$ determination. 


\subsection{Analysis of $\boldsymbol{k}_{\text {Tap }}$ variation with $\mathrm{pH}$}

In this last part of our study, the superoxide radical anion and the protonated hydroperoxyl radical were distinguished. Our purpose was to determine in which extent each of these two species contributes to the $\mathrm{N}-\mathrm{O}_{2} \mathrm{H}$ EPR signal observed. As mentioned in the experimental section, $\mathrm{k}_{\mathrm{O}_{2} . .}$ and $\mathrm{k}_{\mathrm{HO}_{2}}$. are the second-order rate constants for the trapping of $\mathrm{O}_{2}^{-}$and of $\mathrm{HO}_{2}{ }^{-}$by a nitrone $\mathrm{N}$, respectively. Equation (17), which can be rewritten as equation (18), indicates the relation between $\mathrm{k}_{\mathrm{O}_{2}-.,}$ $\mathrm{k}_{\mathrm{HO} 2}$. and $\mathrm{k}_{\mathrm{Tap}}$. Equation(19) can be written from equation (18), in which $\mathrm{pK}_{\mathrm{A}}$ is equal to 4.88 .

$$
\begin{aligned}
& \mathrm{k}_{\mathrm{Tap}}=\left[\mathrm{k}_{\mathrm{HO}_{2} \cdot}+10^{\left(\mathrm{pH}-\mathrm{pK}_{\mathrm{A}}\right)} \mathrm{k}_{\mathrm{O}_{2} \cdot-}\right] /\left[1+10^{(\mathrm{pH}-\mathrm{pK} \mathrm{A})}\right] \\
& \log \mathrm{k}_{\mathrm{T} a p}=\log \left[\mathrm{k}_{\mathrm{HO}_{2} \cdot}+(\mathrm{pH}-4.88) \mathrm{k}_{\mathrm{O}_{2} \cdot-}\right]-\mathrm{pH}+4.88
\end{aligned}
$$

Fitting the model described by equation (18) to the experimental points for nitrones 1-4 yielded the values reported in table 3 for the rate constants $\mathrm{k}_{\mathrm{O}_{2} .}$ and $\mathrm{k}_{\mathrm{HO}_{2}}$. . In figure 5 , the decimal logarithm of $\mathrm{k}_{\text {Tap }}$ has been plotted vs. $\mathrm{pH}$. The curves have been obtained according to equation (19) and using the rate constant values listed in 
table 3, showing for each nitrone a rather good fit between experimental and calculated $\mathrm{k}_{\text {Tap }}$ values.

\section{[Insert figure 5 about here]}

In the particular case of DMPO, $\mathrm{k}_{\mathrm{O}_{2} \text {.. }}$ was found near nil, considering the error in its determination. This last result could seem in contradiction with that published by Goldstein et al. [32], who have found that $\mathrm{k}_{\mathrm{O} 2 \text {-. }}$ was equal to $170 \pm 40 \mathrm{dm}^{3} \mathrm{~mol}^{-1} \mathrm{~s}^{-1}$ for DMPO. However, they obtained this value by measuring the kinetics of $\mathrm{O}_{2}^{-}$ consumption in the presence of $\mathbf{4}$ using the pulse radiolysis technique, while we followed the kinetics of formation of $\mathbf{9}$ using EPR spectroscopy. According to Goldstein et al. [32], only a fraction of the superoxide radical anion yields the nitroxide 9. This explains the discrepancy mentioned above, all the more so since the yield of the reaction: $\mathbf{4}+\mathrm{O}_{2}^{-\cdot} \rightarrow \mathbf{9}$ is unknown. Consequently, the EPR method is obviously more appropriate to kinetic studies of superoxide trapping by nitrones.

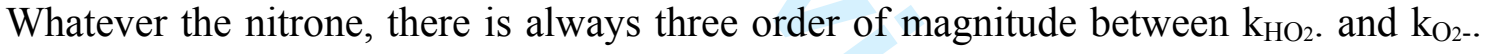
(see table 3). Thus, the trapping of $\mathrm{O}_{2}^{-}$does not intervene significantly in the $\mathrm{N}-\mathrm{O}_{2} \mathrm{H}$ formation until the superoxide concentration is much higher than that of hydroperoxyl radical. For instance, the proportion of the EPR signal of $\mathbf{6}$ originating from the trapping of $\mathrm{O}_{2}^{-\cdot}$ by EMPO is lower than $1 \%$ at $\mathrm{pH} 6.5$, than $2.5 \%$ at $\mathrm{pH} 7$ and than $8 \%$ at $\mathrm{pH} 7.5$. In the case of DMPO 4, these values are raised to ca. $2.5 \%, 8 \%$ and $25 \%$ at $\mathrm{pH} 6.5,7$ and 7.5 respectively. This means that the EPR signals of the spin adducts $\mathrm{N}_{-} \mathrm{O}_{2} \mathrm{H}$ observed in aqueous media around neutral $\mathrm{pH}$ were almost exclusively due to the trapping of the protonated species $\mathrm{HO}_{2}$. 


\section{Conclusion}

This study confirms that the spin trapping of $\mathrm{O}_{2}{ }^{-} / \mathrm{HO}_{2} \cdot$ by nitrones is overall more efficient at low $\mathrm{pH}$. Whatever the nitrone $\mathrm{N}$, the formation of $\mathrm{N}-\mathrm{O}_{2} \mathrm{H}$ is not only faster in acidic media but the decay rate of this spin adduct increases with $\mathrm{pH}$. When it comes to the trapping rate, the same nitrone ranking was obtained at each $\mathrm{pH}$ studied: DEPO was found the fastest at trapping superoxide, followed by EMPO, and TN, these three compounds being much more efficient than DMPO. Examining the $\mathrm{pH}$ dependence of the kinetics of $\mathrm{N}-\mathrm{O}_{2} \mathrm{H}$ formation permitted to evaluate separately the rate constant values for the spin trapping of superoxide radical anion and of hydroperoxyl radical by four nitrones. The results obtained with 1-4 clearly showed that the EPR signals of the nitrone/superoxide spin adducts observed in aqueous media were essentially due to the trapping of the protonated species $\mathrm{HO}_{2}$. For the nitrones tested, $\mathrm{k}_{\mathrm{O}_{2}-}$. was always found lower than $2 \mathrm{dm}^{3} \mathrm{~mol}^{-1} \mathrm{~s}^{-1}$. In previous studies conducted with ten commonly used nitrones, 1-3 were found the most efficient for superoxide/hydroperoxyl radical trapping at neutral $\mathrm{pH}[20-21]$. Thus, this very low reactivity of nitrones with the superoxide radical anion should be considered as a serious drawback, precluding the use of these compounds in quantitative studies of $\mathrm{O}_{2}{ }^{-} / \mathrm{HO}_{2} \cdot$ formation in aqueous media. Despite this, compounds 1-3 could still find interesting applications in qualitative studies in water or biological media. Therefore, the development of new and more efficient traps is still a necessity, in particular for superoxide radical anion detection.

\section{References}

[1] M. Iwamura and N. Inamoto, Bull. Chem. Soc. Jpn, 40, 703 (1967).

[2] E. G. Janzen and B. Blackburn, J. Am. Chem. Soc., 90, 4909 (1968). 
[3] A C. Lagercrantz and S. Forschult, Nature, 218, 1247 (1968).

[4] G. Buettner, Free Rad. Biol. Med., 3, 259 (1987).

[5] G. Buettner and R. Mason, Methods in Enzymol, 186, 127 (1990).

[6] P. Tordo, Electron Paramagnetic Resonance, 16, 117 (1998).

[7] G. Buettner and L. Oberley, Biochem. Biophys. Res. Commun., 83, 69 (1978).

[8] B. Tuccio, R. Lauricella, C. Fréjaville, J. C. Bouteiller and P. Tordo, J. Chem. Soc. Perkin Trans. 2, 295 (1995).

[9] V. Roubaud, R. Lauricella, B. Tuccio, J. C. Bouteiller and P. Tordo, Res. Chem. Intermed., 22, 405 (1996).

[10] G. Olive, A. Mercier, F. Le Moigne, A. Rockenbauer and P. Tordo, Free Rad. Biol. Med., 28, 403 (2000).

[11] F. Villamena and J. Zweier, J. Chem. Soc. Perkin Trans. 2, 1340. (2002).

[12] V. Roubaud, R. Lauricella, J. C. Bouteiller and B. Tuccio, Arch. Biochem. Biophys., 397, 51. (2002).

[13] A. Allouch, V. Roubaud, R. Lauricella, J. C. Bouteiller and B. Tuccio, Org. Biomol. Chem., 1, 593 (2003).

[14] E. Finkelstein, G. Rosen and E. Rauckman, J. Am. Chem. Soc., 102,4994 (1980).

[15] G. Rosen, P. Tsai, J. Weaver, S. Porasuphatana, L. Roman, A. Starkov, G. Fiskum and S. Pou, J. Biol. Chem., 227, 40275 (2002)

[16] P. Tsai, K. Ichikawa, C. Mailer, S. Pou, H. Halpern, B. Robinson, R. Nielsen and G. Rosen, J. Org. Chem., 68, 7811 (2003).

[17] C. Fréjaville, H. Karoui, B. Tuccio, F. Le Moigne, M. Culcasi, S. Pietri, R. Lauricella and P. Tordo, J. Med. Chem., 38, 258 (1995).

[18] I. Yamasaki, L. Piette and T. Grover, J. Biol. Chem., 265, 652 (1990). 
[19] A. Keszler, B. Kalyanaraman and N. Hogg, Free Rad. Biol. Med., 35, 1149 (2003).

[20] R. Lauricella, A. Allouch, V. Roubaud, J. C. Bouteiller and B. Tuccio, Org. Biomol. Chem., 2, 1304 (2004).

[21] A. Allouch, V. Roubaud, R. Lauricella, J. C. Bouteiller and B. Tuccio, Org. Biomol. Chem., 3, 2458 (2005).

[22] R. Lauricella, H. Bouteiller and B. Tuccio, Phys. Chem. Chem. Phys., 7, 399 (2005).

[23] D. Behar, G. Czapski, J. Rabani, L. Dorfman, H. Schwarz, J. Phys. Chem., 1970, 74, 3209

[24] V. Roubaud, H. Dozol, C. Rizzi, R. Lauricella, J. C. Bouteiller and B. Tuccio, J. Chem. Soc. Perkin Trans. 2, 958 (2002).

[25] R. Bonnett, R. Brown, V. Clark, I. Sutherland and S. Todd, J. Chem Soc., 2094 (1959).

[26] G. Olive, A. Mercier, F. Le Moigne, A. Rockenbauer and P. Tordo, Free Rad. Biol. Med., 28, 403 (2000).

[27] H. Karoui, J. L. Clément, A. Rockenbauer, D. Siri and P. Tordo, Tetrahedron Lett., 45, 149 (2004).

[28] W. Press, S. Teukolsky, W. Vetterling and B. Flannery. In Numerical Recipes in FORTRAN: the art of scientific computing, $2^{\text {nd }}$ edn., Cambridge University Press, Cambridge (1992).

[29] J. Baxendale, Radiation Res., 1962, 17, 312 (1962).

[30] D. Duling, J. Magn. Reson. Series B, 104, 5181 (1982).

[31] V. Roubaud, S. Sankarapandi, P. Kuppusamy, P. Tordo and J. Zweier, Anal. Biochem., 247, 404 (1997). 
[32] S. Goldstein, G. Rosen, A. Russo and A. Samuni, J. Phys. Chem. A, 108, 6679 (2004). 


\section{Figure Caption}

Figure 1: Formulae of the nitrone spin traps 1-4 studied.

Figure 2: Formulae of $3 \mathrm{CP} 5$, used as internal reference, and of the spin adducts $\mathrm{N}-\mathrm{O}_{2} \mathrm{H}$ 6-9 studied.

Figure 3: EPR signal obtained in a pH 6.2 buffer by generating superoxide with a xanthine/xanthine oxidase system in the presence of TN $3\left(0.03 \mathrm{~mol} \mathrm{dm}^{-3}\right)$ and of 3 CP $5\left(0.610^{-6} \mathrm{~mol} \mathrm{dm}^{-3}\right)$. The three lines of 5 spectrum are marked by downwards arrows. The other lines belong to the spectrum of $\mathrm{TN}^{-} \mathrm{O}_{2} \mathrm{H} 7$. The framed part corresponds to the signal portion recorded to achieve the kinetic curves.

Figure 4: Experimental (full lines) and calculated (dotted lines) kinetic curves indicating the timedependent changes in $\mathrm{TN}-\mathrm{O}_{2} \mathrm{H} 8$ concentration. A) 8 was produced at $\mathrm{pH} 6.2$ by generating superoxide in the presence of: a) $5 \mathrm{mmol} \mathrm{dm}^{-3}$ 3, b) $30 \mathrm{mmol} \mathrm{dm}^{-3} 3$, and c) $125 \mathrm{mmol} \mathrm{dm}^{-3} \mathbf{3}$. B) 8 was produced at $\mathrm{pH}$ 9.3 by generating superoxide in the presence of: a) $20 \mathrm{mmol} \mathrm{dm}^{-3} 3$, b) $40 \mathrm{mmol} \mathrm{dm}^{-3} 3$, and c) $125 \mathrm{mmol}$ $\mathrm{dm}^{-3}$ 3. Calculated curves, obtained according to the model described by equations. (5)-(8), led to $\mathrm{k}_{\mathrm{Tap}}$ and $\mathrm{k}_{\mathrm{D}}$ values given in table 2 .

Figure 5: Variation of the apparent rate constant $\mathrm{k}_{\mathrm{Tap}}$ with $\mathrm{pH}$ for DEPO $\mathbf{2}(\boldsymbol{\nabla}), \mathrm{EMPO} \mathbf{1}(\bullet), \mathrm{TN} \mathbf{3}(\star)$, and DMPO 4 ( $)$. The curves have been calculated using equation (19) and the rate constant values listed in table 3. Experimental points have been obtained from $\mathrm{k}_{\mathrm{Tap}}$ values listed in table 2. 
Table 1. EPR hyperfine splitting constants for the nitroxides 5-9 in $0.1 \mathrm{~mol} \mathrm{dm}^{-3}$ phosphate buffer ( $\mathrm{pH}$ range: $6.2-9.3$ )

\begin{tabular}{|c|c|c|c|}
\hline & $\mathrm{a}_{\mathrm{N}} / \mathrm{mT}$ & $\mathrm{a}_{\mathrm{H} \beta} / \mathrm{mT}$ & other / $\mathrm{mT}$ \\
\hline 5 & 1.62 & 1 & 1 \\
\hline 6 & 1.32 & 1.09 & $0.10\left(\mathrm{a}_{\mathrm{H} \gamma}\right)$ \\
\hline 7 & 1.26 & 0.99 & $0.12\left(\mathrm{a}_{\mathrm{H} \gamma}\right)$ \\
\hline 8 & 1.34 & 0.16 & $4.24\left(\mathrm{a}_{\mathrm{P}}\right)$ \\
\hline 9 & 1.43 & 1.17 & $0.12\left(\mathrm{a}_{\mathrm{H} \gamma}\right)$ \\
\hline
\end{tabular}


Table 2. Apparent rate constants for the spin trapping of superoxide by nitrones 1-4 $\left(\mathrm{k}_{\mathrm{Tap}}\right)$ and for the decay of nitrone-superoxide spin adducts $\left(\mathrm{k}_{\mathrm{D}}\right)$ at various $\mathrm{pH}$.

\begin{tabular}{|c|c|c|c|c|}
\hline nitrone & $\mathrm{pH}$ & $\mathrm{k}_{\mathrm{Tap}} / \mathrm{dm}^{3} \mathrm{~mol}^{-1} \mathrm{~s}^{-1}$ & {$[\mathrm{~N}] / \mathrm{mmol} \mathrm{dm}^{-3}$} & $\mathrm{k}_{\mathrm{D}} / 10^{-3} \mathrm{~s}^{-1}$ \\
\hline \multirow[t]{15}{*}{ EMPO 1} & 6.2 & $101 \pm 8$ & 150 & $0.88 \pm 0.01$ \\
\hline & & & 30 & $0.48 \pm 0.01$ \\
\hline & & & 10 & $0.45 \pm 0.01$ \\
\hline & 7.2 & $10.9 \pm 0.1$ & 200 & $1.25 \pm 0.04$ \\
\hline & & & 30 & $0.65 \pm 0.04$ \\
\hline & & & 10 & $0.60 \pm 0.04$ \\
\hline & 8.0 & $2.02 \pm 0.08$ & 150 & $0.41 \pm 0.01$ \\
\hline & & & 30 & $0.40 \pm 0.01$ \\
\hline & & & 15 & $0.51 \pm 0.01$ \\
\hline & 8.8 & $0.68 \pm 0.05$ & 150 & $2.66 \pm 0.03$ \\
\hline & & & 30 & $3.68 \pm 0.03$ \\
\hline & & & 10 & $3.56 \pm 0.03$ \\
\hline & 9.3 & $0.60 \pm 0.03$ & 150 & $17.89 \pm 0.78$ \\
\hline & & & 30 & $14.11 \pm 0.78$ \\
\hline & & 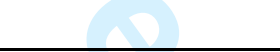 & 10 & $9.38 \pm 0.78$ \\
\hline \multirow[t]{10}{*}{ DEPO 2} & 6.2 & $185 \pm 15$ & 10 & $6.57 \pm 0.29$ \\
\hline & & & 6.5 & $4.41 \pm 0.29$ \\
\hline & 7.2 & $31 \pm 1.3$ & 15 & $2.06 \pm 0.52$ \\
\hline & & & 5 & $1.04 \pm 0.52$ \\
\hline & 8.0 & $3.54 \pm 0.28$ & 10 & $21.28 \pm 0.48$ \\
\hline & & & 6 & $10.60 \pm 0.48$ \\
\hline & 8.8 & $3.18 \pm 0.32$ & 5 & $6.26 \pm 1.35$ \\
\hline & & & 3 & $3.18 \pm 1.35$ \\
\hline & 9.3 & $1.98 \pm 0.11$ & 10 & $15.84 \pm 1.81$ \\
\hline & & & 3 & $10.56 \pm 1.81$ \\
\hline \multirow[t]{15}{*}{ TN 3} & 6.2 & $58.26 \pm 2.67$ & 125 & $2.40 \pm 0.07$ \\
\hline & & & 30 & $1.93 \pm 0.07$ \\
\hline & & & 5 & $1.57 \pm 0.07$ \\
\hline & 7.2 & $8.90 \pm 0.58$ & 140 & $2.70 \pm 0.27$ \\
\hline & & & 72 & $2.60 \pm 0.27$ \\
\hline & & & 5 & $1.90 \pm 0.27$ \\
\hline & 8.0 & $1.56 \pm 0.11$ & 125 & $4.11 \pm 1.0$ \\
\hline & & & 40 & $4.30 \pm 1.0$ \\
\hline & & & 20 & $4.64 \pm 1.0$ \\
\hline & 8.8 & $0.77 \pm 0.09$ & 125 & $5.07 \pm 0.88$ \\
\hline & & & 30 & $3.85 \pm 0.88$ \\
\hline & & & 15 & $2.99 \pm 0.88$ \\
\hline & 9.3 & $0.56 \pm 0.06$ & 125 & $6.59 \pm 0.55$ \\
\hline & & & 40 & $6.10 \pm 0.55$ \\
\hline & & & 20 & $5.49 \pm 0.55$ \\
\hline
\end{tabular}


Table 2 (continued). Apparent rate constants for the spin trapping of superoxide by nitrones 1$4\left(\mathrm{k}_{\mathrm{Tap}}\right)$ and for the decay of nitrone-superoxide spin adducts $\left(\mathrm{k}_{\mathrm{D}}\right)$ at various $\mathrm{pH}$.

\begin{tabular}{|c|c|c|c|c|}
\hline \multirow[t]{5}{*}{ DMPO 4} & 6.2 & $27.48 \pm 1.95$ & $\begin{array}{c}125 \\
40 \\
10\end{array}$ & $\begin{array}{c}0.48 \pm 0.1 \\
0.66 \pm 0.1 \\
0.75 \pm 0.1\end{array}$ \\
\hline & 6.8 & $9.65 \pm 0.60$ & $\begin{array}{c}150 \\
40 \\
30\end{array}$ & $\begin{array}{l}5.4 \pm 1.8 \\
4.9 \pm 1.8 \\
5.4 \pm 1.8\end{array}$ \\
\hline & 7.2 & $2.0 \pm 0.3$ & $\begin{array}{c}125 \\
40 \\
20\end{array}$ & $\begin{array}{l}9.0 \pm 1.7 \\
8.2 \pm 1.7 \\
7.9 \pm 1.7\end{array}$ \\
\hline & 8.0 & $0.52 \pm 0.09$ & $\begin{array}{c}130 \\
75 \\
60\end{array}$ & $\begin{array}{l}15.0 \pm 2.5 \\
14.4 \pm 2.5 \\
11.4 \pm 2.5\end{array}$ \\
\hline & 9.3 & $0.35 \pm 0.04$ & $\begin{array}{c}150 \\
50 \\
30\end{array}$ & $\begin{array}{c}17.7 \pm 4.5 \\
9.1 \pm 4.5 \\
9.2 \pm 4.5\end{array}$ \\
\hline
\end{tabular}


Table 3. Rate constants for the spin trapping of hydroperoxyl radical

\begin{tabular}{cccc} 
& $\left(\mathrm{k}_{\mathrm{HO} 2} \cdot\right)$ and of superoxide $\left(\mathrm{k}_{\mathrm{O} 2 \cdot} \cdot\right)$ by nitrones 1-4. \\
\hline nitrone & $\mathrm{k}_{\mathrm{HO}_{2} \cdot} \cdot / \mathrm{dm}^{3} \mathrm{~mol}^{-1} \mathrm{~s}^{-1}$ & $\mathrm{k}_{\mathrm{O}_{2} \cdot} \cdot / \mathrm{dm}^{3} \mathrm{~mol}^{-1} \mathrm{~s}^{-1}$ & $\mathrm{k}_{\mathrm{HO}_{2} \cdot} / \mathrm{k}_{\mathrm{O}_{2} \cdot} \cdot$ \\
\hline EMPO 1 & $2206 \pm 4$ & $0.41 \pm 0.04$ & $5.3810^{3}$ \\
DEPO 2 & $4015 \pm 30$ & $1.68 \pm 0.65$ & $2.3910^{3}$ \\
TN 3 & $1264 \pm 3$ & $0.57 \pm 0.03$ & $2.2210^{3}$ \\
DMPO 4 & $600 \pm 30$ & $0.34 \pm 0.4$ & $1.7610^{3}$ \\
\hline
\end{tabular}




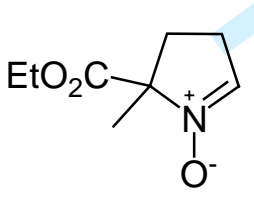

EMPO 1

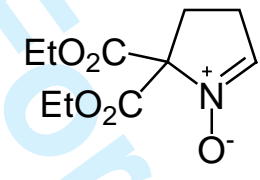

DEPO 2

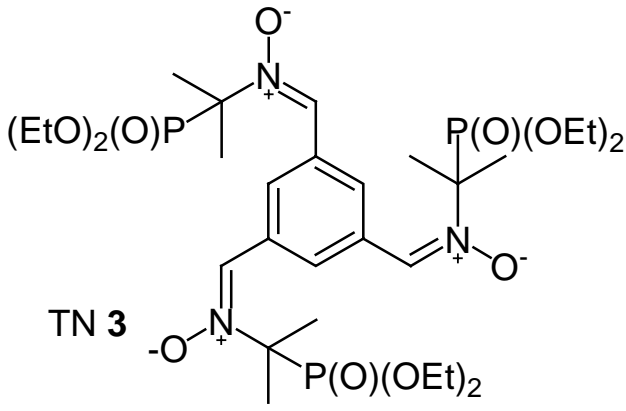

$\overbrace{\substack{N \\ 1 \\ 0^{-}}}$

DMPO 4 
<smiles>CC1(C)CC(C(=O)O)C(C)(C)N1O</smiles>

3CP 5

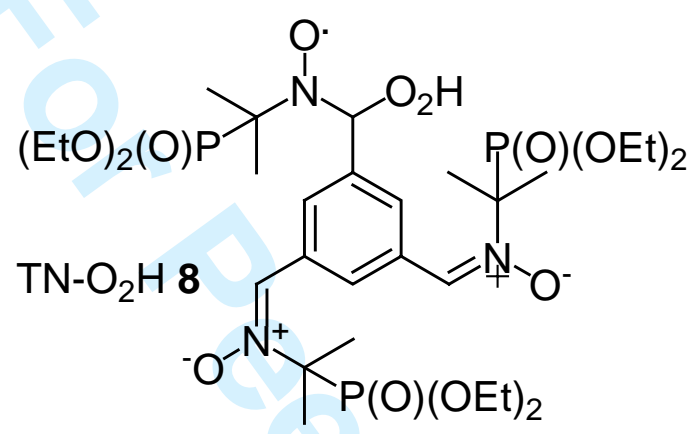<smiles>CCOC(=O)C1(C)CCC(O)N1O</smiles>

EMPO- ${ }_{2} \mathrm{H} 6$

DEPO- $\mathrm{O}_{2} \mathrm{H} 7$<smiles>CCOC(=O)C1(C)CCC(O)N1O</smiles><smiles>CC1(C)CCC(O)N1O</smiles>

DMPO- $\mathrm{O}_{2} \mathrm{H} 9$

Figure 2

A. Allouch et al. $\quad$ pH Effect on Superoxide Trapping by Nitrones 


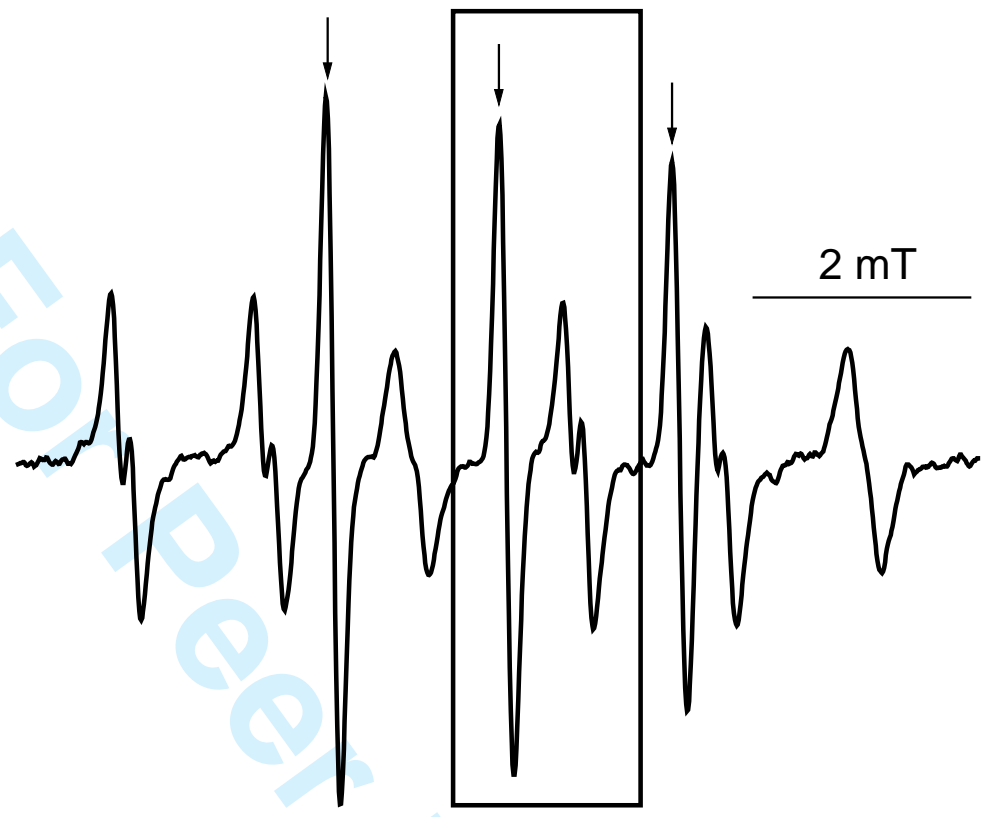

Figure 3

A. Allouch et al. $\quad$ pH Effect on Superoxide Trapping by Nitrones 

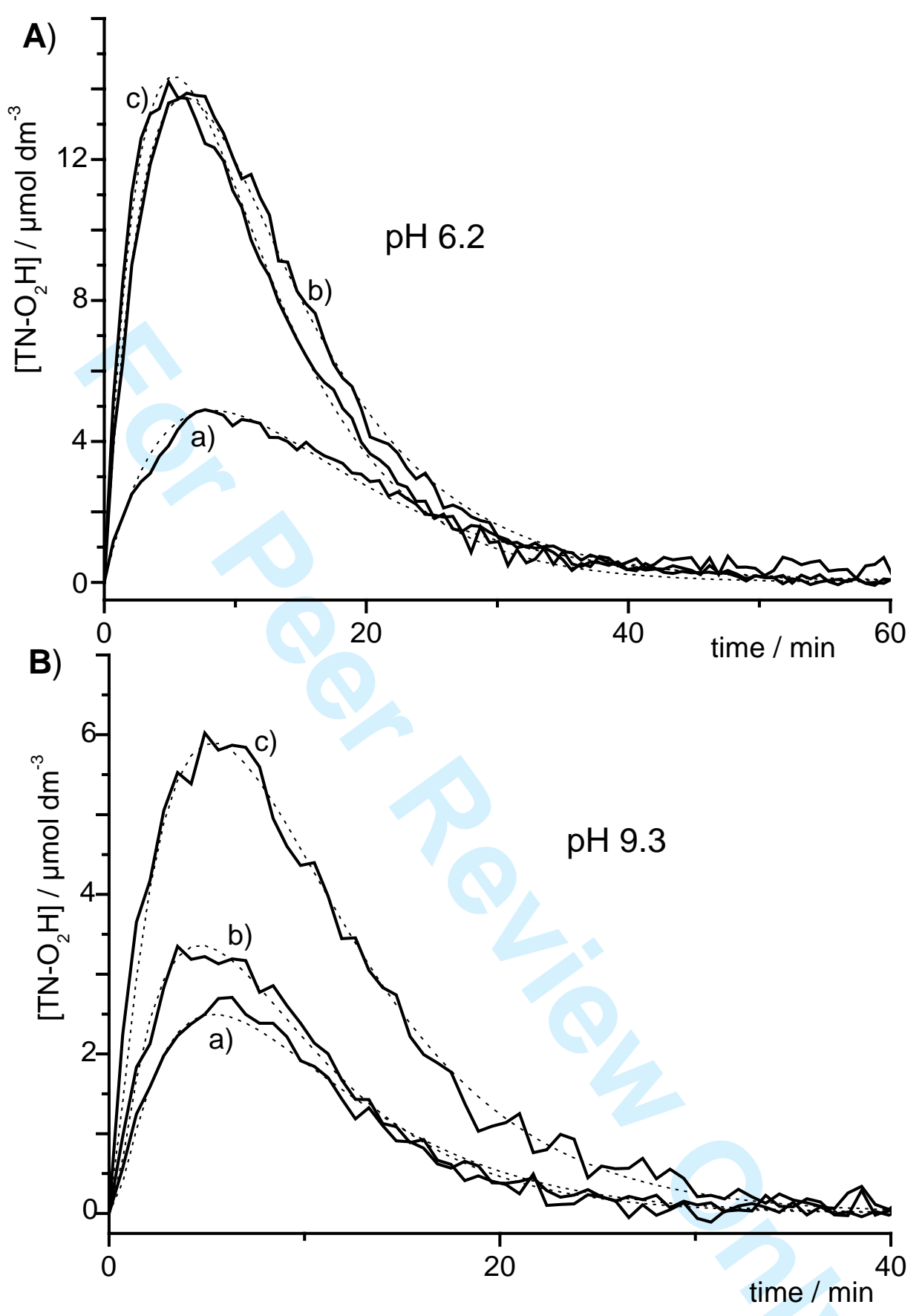

Figure 4 A. Allouch et al. $\quad$ pH Effect on Superoxide Trapping by Nitrones 


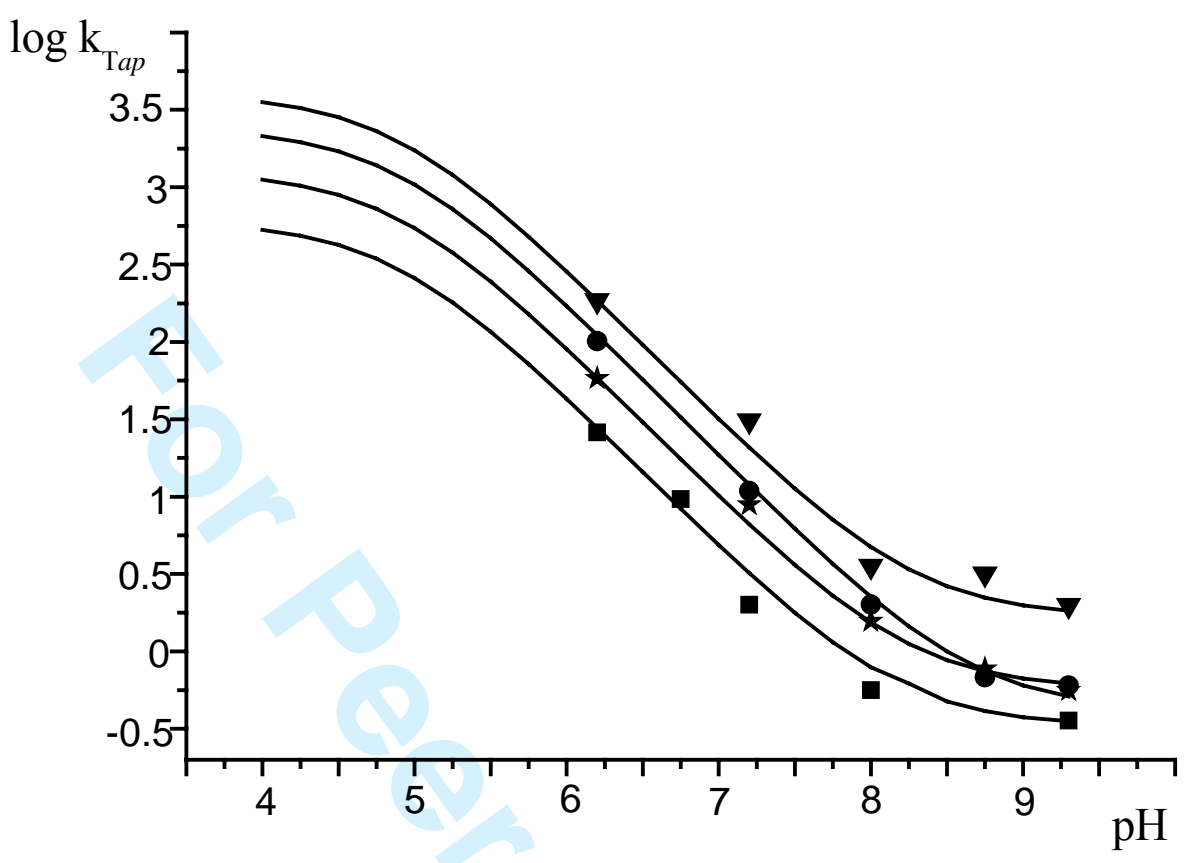

Figure $5 \quad$ A. Allouch et al. $\quad$ pH Effect on Superoxide Trapping by Nitrones 
Molecular Physics, Vol. X, No. X, Month 2007, xxx-xxx

A. Allouch et al. $\quad$ pH Effect on Superoxide Trapping by Nitrones

\title{
Effect of pH on superoxide/ hydroperoxyl radical
}

\section{trapping by nitrones: an EPR/kinetic study}

\author{
A. ALLOUCH, R. P. LAURICELLA and B. N. TUCCIO* \\ Laboratoire TRACES, Aix-Marseille Universités, case 512, Faculté de St Jérôme, \\ 13397 Marseille cedex 20, France. \\ *Corresponding author. Email: tuccio@up.univ-mrs.fr
}

The $\mathrm{pH}$ dependence of the apparent rate constant $\mathrm{k}_{\mathrm{T} a p}$ for $\mathrm{O}_{2}{ }^{-} / \mathrm{HO}_{2}$ trapping by four nitrones was examined. In each case, kinetic curves were obtained after treatment of EPR spectra of the spin adduct formed using both singular value decomposition and pseudo-inverse deconvolution methods. Modelling these curves led to evaluate $\mathrm{k}_{\mathrm{T} a p}$ at various $\mathrm{pH}$ values. Analysis of the $\mathrm{pH}$ dependence of $\mathrm{k}_{\mathrm{T} a p}$ permitted the determination of the rate constants for the spin trapping of $\mathrm{O}_{2}{ }^{-}$and of $\mathrm{HO}_{2}{ }^{\cdot}$ separately. Whatever the nitrone, our results clearly show that the EPR signals of the nitrone/superoxide spin adducts observed in aqueous media were essentially due to the trapping of the protonated species $\mathrm{HO}_{2}$

Keywords: EPR; Kinetics; pH Effect; Spin Trapping; Superoxide; Nitrones 


\section{Introduction}

Since the EPR/spin trapping technique was first introduced [1-3], it has found numerous applications in the detection of free radicals produced in chemistry, biology or medicine. It has been notably employed for detecting superoxide in aqueous media using nitrone spin traps [4-6]. For this purpose, a nitrone must trap rapidly this radical and must lead to a long-lived spin adduct. Several reliable methods have been described to determine $\mathrm{k}_{\mathrm{D}}$, the rate constant for the nitrone/superoxide spin adduct decay [7-13]. In contrast, evaluating the apparent rate of superoxide trapping by a nitrone, $\mathrm{k}_{\mathrm{T} a p}$, is more problematic and major disagreements exist regarding the data published in this field [11,14-21]. The most popular method used in these studies involves a competition between the nitrone and a superoxide scavenger, and implies that the superoxide spontaneous dismutation, the spin adduct decay and the consumption of the competitor during the course of the experiment correspond to negligible events [11,14-17]. Two years ago, we brought evidences of the importance of these three reactions and showed that their omission resulted in significantly overestimating $\mathrm{k}_{\mathrm{T} a p}$ [22]. Another method based on a competition between the superoxide trapping by the nitrone and the spontaneous dismutation of this radical yielded lower $\mathrm{k}_{\text {Tap }}$ values []18,19]. This prompted us to elaborate a new kinetic approach to the evaluation of $\mathrm{k}_{\mathrm{T} a p}$ in buffered media [20,21]. It was also based on a competition between the superoxide trapping and its spontaneous dismutation, and kinetic curves were obtained after treatment of EPR spectra using both singular value decomposition (SVD) and pseudo-inverse deconvolution methods before their computer modelling. Whatever the method used, it is widely admitted that the kinetic parameters related to the spin trapping of superoxide by nitrones are $\mathrm{pH}$ dependent. On one hand, nitrone/superoxide spin adducts decayed 
more slowly in acidic media [7-9]. On the other hand, $\mathrm{k}_{\mathrm{T} a p}$ also greatly varied with $\mathrm{pH}$ $[14,16]$, owing to the fact that superoxide $\mathrm{O}_{2}{ }^{-}$and its protonated form $\mathrm{HO}_{2}$ were not distinguished in these studies, both radicals leading to the same EPR-detectable spin adduct in aqueous media. The relative concentrations of $\mathrm{HO}_{2}{ }^{\cdot}$ and of $\mathrm{O}_{2}^{-\cdot}$ depend on $\mathrm{pH}$, the $\mathrm{pK}_{\mathrm{A}}$ value for the acidic dissociation reaction of the hydroperoxyl radical being equal to 4.88 [23]. Considering that nitrones react differently with $\mathrm{HO}_{2}{ }^{\cdot}$ and $\mathrm{O}_{2}{ }^{-}$, this justifies the $\mathrm{pH}$ dependence of $\mathrm{k}_{\mathrm{T} a p}$.

Recently, we have found that three nitrones were particularly efficient for superoxide detection: the ethyl 2-methyl-3,4-dihydro-2H-pyrrole-carboxylate 1 -oxide 1 (EMPO, $\mathrm{k}_{\mathrm{T} a p} \approx 11 \mathrm{dm}^{3} \mathrm{~mol}^{-1} \mathrm{~s}^{-1}$ at $\mathrm{pH} 7.2$ ), the diethyl 3,4-dihydro-2H-pyrrole-2,2-dicarboxylate 1-oxide 2 (DEPO, $\mathrm{k}_{\mathrm{Ta}} \approx 31 \mathrm{dm}^{3} \mathrm{~mol}^{-1} \mathrm{~s}^{-1}$ at $\mathrm{pH}$ 7.2), and 1,3,5-tri [(N- (1diethylphosphono)-1-methyl-ethyl) - $N$-oxy-aldimine] benzene 3 (TN, $\mathrm{k}_{\mathrm{Tap}} \approx 9 \mathrm{dm}^{3} \mathrm{~mol}^{-}$ ${ }^{1} \mathrm{~s}^{-1}$ at $\mathrm{pH}$ 7.2) [20,21]. Among them, TN is the only lipophilic trap, with an octanol/water partition coefficient higher than 300 [24]. By far, DEPO was found the fastest at trapping superoxide, but the spin adduct thus formed decayed very rapidly, particularly when high nitrone concentrations were used. However, kinetic experiments with all these traps were only performed at $\mathrm{pH}$ 7.2. To proceed with this study, we have examined the $\mathrm{pH}$ dependence of the rate constant for the superoxide trapping by EMPO, DEPO, TN and have compared the results obtained to that given by the well-known 2,2dimethyl-3,4-dihydro-2H-pyrrole 1 -oxide 4 (DMPO) (see figure 1). Analysis of the data obtained at various $\mathrm{pH}$ permitted to evaluate separately the rate constant for the trapping of $\mathrm{HO}_{2}{ }^{-}$and $\mathrm{O}_{2}^{-}$by the nitrone considered and to determine which species is actually responsible for the formation of the adduct detected by EPR.

\section{[Insert figure 1 about here]}


In this whole study, the spin adduct detected by EPR after trapping either $\mathrm{O}_{2}{ }^{-}$or $\mathrm{HO}_{2}{ }^{*}$ with a nitrone $\mathrm{N}$ in aqueous media will be denoted $\mathrm{N}-\mathrm{O}_{2} \mathrm{H}$. With the aim of simplifying the notation, the term 'superoxide' will first be used to designate both superoxide and hydroperoxyl radicals as a whole in the part of this work devoted to the study of the $\mathrm{pH}$ effect on $\mathrm{k}_{\mathrm{T} a p}$. Similarly, the symbol ' $\mathrm{O}_{2}^{-\cdot}$ ' in the kinetic model [equations (1)-(4)] as well as in the rate equations (5)-(8) will represent either protonated or non-protonated forms of the radical. In a second part of this study, the two species will be considered separately to evaluate each individual contribution to the formation of $\mathrm{N}-\mathrm{O}_{2} \mathrm{H}$.

\section{Experimentals}

\subsection{Materials}

The nitrones EMPO 1, DEPO 2 and TN 3 were synthesised and purified according to procedures described previously [24-27]. DMPO 4 (Sigma-Aldrich Co.) was purified by vacuum distillation before use. Diethylenetriaminepentacetic acid (DTPA), 3-carboxy2,2,5,5-tetramethylpyrrolidin-1-oxyl 5 (3CP), xanthine and xanthine oxidase were obtained from Sigma-Aldrich Co. Buffer solutions, were stirred gently for six hours in the presence of a chelating iminodiacetic acid resin to remove trace metal impurities.

\subsection{Achievement of experimental kinetic curves}

All experiments were made in $0.1 \mathrm{~mol} \mathrm{dm}^{-3}$ phosphate buffer (pH range: 6.2-9.3). Superoxide was produced using a xanthine-xanthine oxidase system. In a standard experiment, the medium contained a nitrone $\mathrm{N}\left(3-200 \mathrm{mmol} . \mathrm{dm}^{-3}\right), 1.6 \mathrm{mmol} . \mathrm{dm}^{-3}$ xanthine, $3 \mathrm{mmol} . \mathrm{dm}^{-3}$ diethylenetriaminepentacetic acid, $3 \mathrm{CP}\left(0.5-1.1 \mu \mathrm{mol} \mathrm{dm}{ }^{-3}\right)$ used as internal standard, and 0.04 unit. $\mathrm{cm}^{-3}$ xanthine oxidase. Air was bubbled into the 


\subsection{Determination of the apparent rate constant $k_{\text {Tap }}$}

At a given $\mathrm{pH}$, the kinetic model considered can be described by equations (1)-(4),

$$
\begin{aligned}
& \mathrm{X} \stackrel{\mathrm{k}_{\mathrm{X}}}{\longrightarrow} \mathrm{O}_{2}^{-\cdot} \\
& 2 \mathrm{O}_{2}^{--}+2 \mathrm{H}^{+} \stackrel{\mathrm{k}_{\mathrm{dis}}}{\longrightarrow} \mathrm{O}_{2}+\mathrm{H}_{2} \mathrm{O}_{2} \\
& \mathrm{O}_{2}^{--}+\mathrm{H}^{+}+\mathrm{N} \stackrel{\mathrm{k}_{\mathrm{T} a p}}{\longrightarrow}{\mathrm{N}-\mathrm{O}_{2} \mathrm{H}} \\
& \mathrm{N}-\mathrm{O}_{2} \mathrm{H} \stackrel{\mathrm{k}_{\mathrm{D}}}{\longrightarrow} \mathrm{Y}
\end{aligned}
$$


where $\mathrm{k}_{\mathrm{X}}$ and $\mathrm{k}_{\mathrm{D}}$ are the rate constants for the generation of superoxide and for the decay of the spin adduct $\mathrm{N}-\mathrm{O}_{2} \mathrm{H}$, respectively, $\mathrm{Y}$ representing EPR silent products and $\mathrm{X}$ an intermediate derived from xanthine [20]. The apparent rate constant for the secondorder trapping reaction is denoted $\mathrm{k}_{\mathrm{Tap}}$. The rate equations (5)-(8) can be written from this kinetic model:

$$
\begin{aligned}
& \mathrm{d}[\mathrm{X}] / \mathrm{dt}=-\mathrm{k}_{\mathrm{X}}[\mathrm{X}] \\
& \mathrm{d}\left[\mathrm{O}_{2}^{--}\right] / \mathrm{dt}=\mathrm{k}_{\mathrm{X}}[\mathrm{X}]-\mathrm{k}_{\mathrm{T} a p}[\mathrm{~N}]\left[\mathrm{O}_{2}^{-\cdot}\right]-2 \mathrm{k}_{\mathrm{dis}}\left[\mathrm{O}_{2}^{-\cdot}\right]^{2} \\
& \mathrm{~d}\left[\mathrm{~N}-\mathrm{O}_{2} \mathrm{H}\right] / \mathrm{dt}=\mathrm{k}_{\mathrm{T} a p}[\mathrm{~N}]\left[\mathrm{O}_{2}^{-\cdot}\right]-\mathrm{k}_{\mathrm{D}}\left[\mathrm{N}-\mathrm{O}_{2} \mathrm{H}\right] \\
& \mathrm{d}[\mathrm{N}] / \mathrm{dt}=-\mathrm{k}_{\mathrm{T} a p}[\mathrm{~N}]\left[\mathrm{O}_{2}^{-\cdot}\right]
\end{aligned}
$$

The term 'superoxide' and the symbol ' $\mathrm{O}_{2}^{-}$', designate here the protonated and nonprotonated forms of the radical indiscriminately. The apparent rate constant for the trapping reaction by the nitrone $\mathrm{N}, \mathrm{k}_{\mathrm{T} a p}$, is $\mathrm{pH}$ dependent and includes the contribution of both $\mathrm{HO}_{2}$ and $\mathrm{O}_{2}^{-}$trapping. The second order rate constant for the superoxide spontaneous dismutation reaction, $\mathrm{k}_{\mathrm{dis}}$, is also $\mathrm{pH}$-dependent. Computer modelling of the kinetic curves obtained was achieved using a home-made programme and according to equations (5)-(8). In these calculations, the nitrone initial concentration is an experimental parameter, the initial concentrations of superoxide and of $\mathrm{N}-\mathrm{O}_{2} \mathrm{H}$ are equal to zero, and $\mathrm{k}_{\mathrm{dis}}$ was evaluated as described further. The standard least-square method was applied to fit the experimental curves, yielding the other parameters. Therefore, the three kinetic curves obtained at three different nitrone concentrations were considered jointly and modelled with the same parameter set (except for parameters varying with the nitrone concentration). The values obtained for the initial concentration $[\mathrm{X}]_{0}$ and for the rate constant $\mathrm{k}_{\mathrm{X}}$ had no real meaning and only came up as an empirical model of the superoxide generation. Since they may vary with the solutions of either xanthine or 
xanthine oxidase used [20], experiments at various nitrone concentrations were performed with exactly the same superoxide generator. The model corresponding to equations (9)-(12), which was first established by Baxendale [29], describes the superoxide spontaneous dismutation in aqueous media. Here, reaction (12) is negligible below pH 9.5.

$$
\begin{aligned}
& \mathrm{HO}_{2} \stackrel{\mathrm{K}_{\mathrm{A}}}{\longrightarrow} \mathrm{O}_{2}^{-\cdot}+\mathrm{H}^{+} \\
& 2 \mathrm{HO}_{2} \stackrel{\mathrm{k}_{1}}{\longrightarrow} \mathrm{H}_{2} \mathrm{O}_{2}+\mathrm{O}_{2} \\
& \mathrm{O}_{2}^{-\cdot}+\mathrm{HO}_{2} \stackrel{\mathrm{k}_{2}}{\longrightarrow} \mathrm{H}_{2} \mathrm{O}_{2}+\mathrm{O}_{2}+\mathrm{HO}^{-} \\
& 2 \mathrm{O}_{2}^{-\cdot} \stackrel{\mathrm{k}_{3}}{\longrightarrow} \mathrm{H}_{2} \mathrm{O}_{2}+\mathrm{O}_{2}+2 \mathrm{HO}^{-}
\end{aligned}
$$

The rate constant $\mathrm{k}_{\mathrm{dis}}$ can be determined at any $\mathrm{pH}$ from equations (13)-(14), where $\mathrm{pK}_{\mathrm{A}}, \mathrm{k}_{1}$ and $\mathrm{k}_{2}$ are equal to $4.88,7610^{4} \mathrm{dm}^{3} \cdot \mathrm{mol}^{-1} \cdot \mathrm{s}^{-1}$ and $8510^{6} \mathrm{dm}^{3} \cdot \mathrm{mol}^{-1} \cdot \mathrm{s}^{-1}$, respectively [23].

$$
\begin{aligned}
& \mathrm{k}_{\mathrm{dis}}=\left(\mathrm{k}_{1}+\chi \mathrm{k}_{2}\right) /(1+\chi)^{2} \\
& \chi=\mathrm{K}_{\mathrm{A}} /\left[\mathrm{H}^{+}\right]=10^{\left(\mathrm{pH}-\mathrm{pK}_{\mathrm{A}}\right)}
\end{aligned}
$$

\subsection{Determination of the trapping rate constants $k_{\mathrm{HO}_{2}}$ and $k_{\mathrm{O}_{2}-\text {. }}$}

Because nitrones react differently with $\mathrm{O}_{2}{ }^{-}$and with $\mathrm{HO}_{2}$, reactions (15) and (16) should be considered instead of reaction (3) in the kinetic model, $\mathrm{k}_{\mathrm{HO}_{2}}$. and $\mathrm{k}_{\mathrm{O}_{2}-\text {. being }}$ the rate constants for the trapping of superoxide radical anion $\left(\mathrm{O}_{2}^{-}\right)$and hydroperoxyl radical $\left(\mathrm{HO}_{2}\right)$, respectively, by the nitrone $\mathrm{N}$.

$$
\begin{aligned}
& \mathrm{O}_{2}^{-\cdot}+\mathrm{N}+\mathrm{H}^{+} \stackrel{\mathrm{k}_{\mathrm{O}^{-} \cdot}}{\longrightarrow} \mathrm{N}-\mathrm{O}_{2} \mathrm{H} \\
& \mathrm{HO}_{2}+\mathrm{N} \stackrel{\mathrm{k}_{\mathrm{HO} 2 \cdot}}{\longrightarrow} \mathrm{N}-\mathrm{O}_{2} \mathrm{H}
\end{aligned}
$$


According to Finkelstein et al. [14], equation. (17) can be written from equations (14)(16).

$$
\mathrm{k}_{\mathrm{T} a p}=\left(\mathrm{k}_{\mathrm{HO} 2 \cdot}+\chi \mathrm{k}_{\mathrm{O} 2 \cdot}-\right) /(1+\chi)
$$

Using the method described in the previous section, $\mathrm{k}_{\mathrm{T} a p}$ was determined for each nitrone at five $\mathrm{pH}$ values ranging from 6.2 to 9.3. The experimental curves thus obtained were modelled using equation (17), which led to $\mathrm{k}_{\mathrm{HO} 2}$. and $\mathrm{k}_{\mathrm{O}_{2} \cdot-\text {. }}$

\section{Results and discussion}

\subsection{Determination of the rate constants at various $\mathrm{pH}$}

Experiments were performed in order to evaluate the $\mathrm{pH}$ influence on the trapping of superoxide by four nitrones: EMPO 1, DEPO 2, TN 3 and DMPO 4. Whatever the species trapped by the nitrone $\mathrm{N}\left(\mathrm{O}_{2}^{-}\right.$or $\mathrm{HO}_{2}{ }^{-}$, both designated here by the term 'superoxide'), only the protonated adduct $\mathrm{N}-\mathrm{O}_{2} \mathrm{H}$ will be detected by EPR. Actually, the anionic radical species $\mathrm{N}_{-} \mathrm{O}_{2}^{-}$is not EPR silent, but its concentration in the $\mathrm{pH}$ range considered is negligible, considering the high $\mathrm{pKa}$ values of hydroperoxides.

The formulae of the stable nitroxide 5 and of the spin adducts 6-9 considered in this study have been drawn in figure 2. Before each kinetic experiment, a full EPR spectrum of the medium was recorded. All the spectra thus obtained were analysed using the computer program elaborated by Duling [30], which led to the values listed in table 1 for the hyperfine splitting constants (hfscs) with the nitrogen $\left(\mathrm{a}_{N}\right)$, the $\beta$-hydrogen $\left(a_{H \beta}\right)$ and eventually a $\gamma$-hydrogen $\left(a_{H \gamma}\right)$ or a $\beta$-phosphorus $\left(a_{P}\right)$ nuclei. These hfscs were not found to vary in the $\mathrm{pH}$ range considered and agree with the literature data $[4,10,24,27]$. In a previous study [24], we have shown that 
the mono-nitroxide 8 (i.e. the mono-adduct) was almost exclusively formed at the tri-nitrone TN 3 concentrations used, the proportion of bi-nitroxide being negligible.

\section{[Insert figure 2 and table 1 about here]}

The kinetic approach used, based on a competition between the superoxide trapping and its spontaneous dismutation at a given $\mathrm{pH}$ value, permits the consideration of the whole kinetic curve of superoxide adduct formation and decay. This method has been extensively described elsewhere and will only be briefly explained here [20]. For each nitrone $\mathrm{N}$ considered and at each $\mathrm{pH}$ value studied, a part of the EPR spectrum of $\mathrm{N}-\mathrm{O}_{2} \mathrm{H}$ was recorded as a function of time at various nitrone concentrations, in the presence of an internal reference (see experimental section). In order to illustrate the method employed, an EPR spectrum of the adduct $\mathrm{TN}^{-} \mathrm{O}_{2} \mathrm{H} 8$ recorded at $\mathrm{pH} 6.2$ in the presence of the internal standard 3CP is shown in figure 3, the framed part corresponding to the signal range chosen to perform the kinetic experiments. Using both singular value decomposition and pseudo-inverse deconvolution methods, kinetic curves indicating the time dependant changes in the $\mathrm{N}-\mathrm{O}_{2} \mathrm{H}$ concentration at various $\mathrm{pH}$ were achieved. As an example, the curves obtained with the spin trap 3 at $\mathrm{pH} 6.2$ and at $\mathrm{pH} 9.3$ are given in figure 4 . Using equations. (5)-(8), computer modelling of the experimental kinetic curves obtained with each nitrone at each $\mathrm{pH}$ considered yielded the values of $\mathrm{k}_{\mathrm{D}}$ and $\mathrm{k}_{\text {Tap }}$ listed in table 2 .

\section{[Insert figures 3 and 4 and table 2 about here]}

It has been shown that the rate constant for the first-order decay of nitrone/superoxide spin adducts increased with $\mathrm{pH}$ and with the spin trap concentration [7-9,20,21,30]. Overall, the values listed for $k_{D}$ in table 2 agree with 
these observations, though a few deviations from this general trend can be noticed. These could be explained by considering two main factors. Firstly, EPR signals recorded under certain extreme conditions (e.g. at high $\mathrm{pH}$ values) were often very weak. Actually, it would have been impossible to achieve the kinetic curves from these spectra without the help of SVD and deconvolution methods. In this case, $\mathrm{k}_{\mathrm{D}}$ determination could be less accurate, as shown for instance by the errors given in table 2. Secondly, the first-order decay of nitrone/superoxide spin adducts in aqueous media are known to depend on several parameters other than $\mathrm{pH}$ and nitrone concentration. In particular, minor changes in the superoxide generator (i.e. in solutions of xanthine or of xanthine oxidase) may affect significantly $\mathrm{N}-\mathrm{O}_{2} \mathrm{H}$ lifetime $[8,10,20,21]$. Considering the number of experiments performed in this study, different solutions of xanthine and of xanthine oxidase have been used, thereby rending $k_{D}$ evaluation less accurate. The dependence of the decay rate of nitrone/superoxide adducts on various parameters ( $\mathrm{pH}$, nitrone concentration, superoxide generating system, etc.) is certainly an interesting problem that would warrant a more thorough study. A better knowledge of the mechanisms responsible for $\mathrm{N}-\mathrm{O}_{2} \mathrm{H}$ decay in aqueous solutions would permit the design of new spin traps with increased superoxide adduct life-time. However, the purpose of the present work was mainly to scrutinise the effect of $\mathrm{pH}$ on the superoxide trapping rate. Note that the three series of spectra at the three different nitrone concentrations, for each nitrone and at each $\mathrm{pH}$, were recorded under exactly the same conditions. Thus, in the kinetic approach used, minor changes in the superoxide generator would not affect $\mathrm{k}_{\mathrm{T} a p}$ determination. 


\subsection{Analysis of $k_{T a p}$ variation with $p H$}

In this last part of our study, the superoxide radical anion and the protonated hydroperoxyl radical were distinguished. Our purpose was to determine in which extent each of these two species contributes to the $\mathrm{N}-\mathrm{O}_{2} \mathrm{H}$ EPR signal observed. As mentioned in the experimental section, $\mathrm{k}_{\mathrm{O}_{2} \text {-. }}$ and $\mathrm{k}_{\mathrm{HO}_{2}}$. are the second-order rate constants for the trapping of $\mathrm{O}_{2}^{-}$and of $\mathrm{HO}_{2}{ }^{-}$by a nitrone $\mathrm{N}$, respectively. Equation (17), which can be rewritten as equation (18), indicates the relation between $\mathrm{k}_{\mathrm{O}_{2-.}}$, $\mathrm{k}_{\mathrm{HO}_{2}}$. and $\mathrm{k}_{\text {Tap }}$. Equation(19) can be written from equation (18), in which $\mathrm{pK}_{\mathrm{A}}$ is equal to 4.88 .

$$
\begin{aligned}
& \mathrm{k}_{\mathrm{T} a p}=\left[\mathrm{k}_{\mathrm{HO}_{2} \cdot}+10^{\left(\mathrm{pH}-\mathrm{pK}_{\mathrm{A}}\right)} \mathrm{k}_{\mathrm{O}_{2} \cdot-}\right] /\left[1+10^{\left(\mathrm{pH}-\mathrm{pK}_{\mathrm{A}}\right)}\right] \\
& \log \mathrm{k}_{\mathrm{T} a p}=\log \left[\mathrm{k}_{\mathrm{HO} 2 \cdot}+(\mathrm{pH}-4.88) \mathrm{k}_{\mathrm{O}_{2} \cdot-}\right]-\mathrm{pH}+4.88
\end{aligned}
$$

Fitting the model described by equation (18) to the experimental points for nitrones 1-4 yielded the values reported in table 3 for the rate constants $\mathrm{k}_{\mathrm{O}_{2} \text {. }}$ and $\mathrm{k}_{\mathrm{HO}_{2}}$. In figure 5, the decimal logarithm of $\mathrm{k}_{\mathrm{T} a p}$ has been plotted $v s . \mathrm{pH}$. The curves have been obtained according to equation (19) and using the rate constant values listed in 
table 3, showing for each nitrone a rather good fit between experimental and calculated $\mathrm{k}_{\mathrm{T} a p}$ values.

\section{[Insert figure 5 about here]}

In the particular case of DMPO, $\mathrm{k}_{\mathrm{O}_{2} \text {.. }}$ was found near nil, considering the error in its determination. This last result could seem in contradiction with that published by

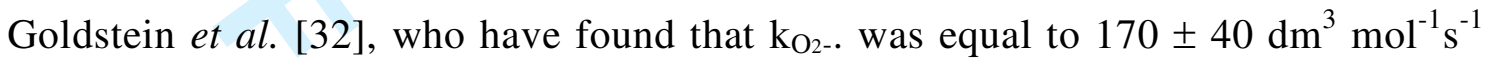
for DMPO. However, they obtained this value by measuring the kinetics of $\mathrm{O}_{2}^{-}$ consumption in the presence of $\mathbf{4}$ using the pulse radiolysis technique, while we followed the kinetics of formation of 9 using EPR spectroscopy. According to Goldstein et al. [32], only a fraction of the superoxide radical anion yields the nitroxide 9. This explains the discrepancy mentioned above, all the more so since the yield of the reaction: $4+\mathrm{O}_{2}^{-\cdot} \rightarrow \mathbf{9}$ is unknown. Consequently, the EPR method is obviously more appropriate to kinetic studies of superoxide trapping by nitrones.

Whatever the nitrone, there is always three order of magnitude between $\mathrm{k}_{\mathrm{HO}_{2}}$. and $\mathrm{k}_{\mathrm{O}_{2}-}$. (see table 3). Thus, the trapping of $\mathrm{O}_{2}{ }^{-}$does not intervene significantly in the $\mathrm{N}-\mathrm{O}_{2} \mathrm{H}$ formation until the superoxide concentration is much higher than that of hydroperoxyl radical. For instance, the proportion of the EPR signal of $\mathbf{6}$ originating from the trapping of $\mathrm{O}_{2}^{-}$by EMPO is lower than $1 \%$ at $\mathrm{pH} 6.5$, than $2.5 \%$ at $\mathrm{pH} 7$ and than $8 \%$ at $\mathrm{pH} 7.5$. In the case of DMPO 4, these values are raised to $c a .2 .5 \%, 8 \%$ and $25 \%$ at $\mathrm{pH} 6.5,7$ and 7.5 respectively. This means that the EPR signals of the spin adducts $\mathrm{N}-\mathrm{O}_{2} \mathrm{H}$ observed in aqueous media around neutral $\mathrm{pH}$ were almost exclusively due to the trapping of the protonated species $\mathrm{HO}_{2}$. 


\section{Conclusion}

This study confirms that the spin trapping of $\mathrm{O}_{2}{ }^{-} / \mathrm{HO}_{2}{ }^{\circ}$ by nitrones is overall more efficient at low $\mathrm{pH}$. Whatever the nitrone $\mathrm{N}$, the formation of $\mathrm{N}-\mathrm{O}_{2} \mathrm{H}$ is not only faster in acidic media but the decay rate of this spin adduct increases with $\mathrm{pH}$. When it comes to the trapping rate, the same nitrone ranking was obtained at each $\mathrm{pH}$ studied: DEPO was found the fastest at trapping superoxide, followed by EMPO, and TN, these three compounds being much more efficient than DMPO. Examining the $\mathrm{pH}$ dependence of the kinetics of $\mathrm{N}-\mathrm{O}_{2} \mathrm{H}$ formation permitted to evaluate separately the rate constant values for the spin trapping of superoxide radical anion and of hydroperoxyl radical by four nitrones. The results obtained with 1-4 clearly showed that the EPR signals of the nitrone/superoxide spin adducts observed in aqueous media were essentially due to the trapping of the protonated species $\mathrm{HO}_{2}$. For the nitrones tested, $\mathrm{k}_{\mathrm{O}^{-}}$. was always found lower than $2 \mathrm{dm}^{3} \mathrm{~mol}^{-1} \mathrm{~s}^{-1}$. In previous studies conducted with ten commonly used nitrones, 1-3 were found the most efficient for superoxide/hydroperoxyl radical trapping at neutral $\mathrm{pH}[20-21]$. Thus, this very low reactivity of nitrones with the superoxide radical anion should be considered as a serious drawback, precluding the use of these compounds in quantitative studies of $\mathrm{O}_{2}{ }^{-} / \mathrm{HO}_{2}$ formation in aqueous media. Despite this, compounds 1-3 could still find interesting applications in qualitative studies in water or biological media. Therefore, the development of new and more efficient traps is still a necessity, in particular for superoxide radical anion detection.

\section{References}

[1] M. Iwamura and N. Inamoto, Bull. Chem. Soc. Jpn, 40, 703 (1967).

[2] E. G. Janzen and B. Blackburn, J. Am. Chem. Soc., 90, 4909 (1968). 
[3] A C. Lagercrantz and S. Forschult, Nature, 218, 1247 (1968).

[4] G. Buettner, Free Rad. Biol. Med., 3, 259 (1987).

[5] G. Buettner and R. Mason, Methods in Enzymol, 186, 127 (1990).

[6] P. Tordo, Electron Paramagnetic Resonance, 16, 117 (1998).

[7] G. Buettner and L. Oberley, Biochem. Biophys. Res. Commun., 83, 69 (1978).

[8] B. Tuccio, R. Lauricella, C. Fréjaville, J. C. Bouteiller and P. Tordo, J. Chem. Soc. Perkin Trans. 2, 295 (1995).

[9] V. Roubaud, R. Lauricella, B. Tuccio, J. C. Bouteiller and P. Tordo, Res. Chem. Intermed., 22, 405 (1996).

[10] G. Olive, A. Mercier, F. Le Moigne, A. Rockenbauer and P. Tordo, Free Rad. Biol. Med., 28, 403 (2000).

[11] F. Villamena and J. Zweier, J. Chem. Soc. Perkin Trans. 2, 1340. (2002).

[12] V. Roubaud, R. Lauricella, J. C. Bouteiller and B. Tuccio, Arch. Biochem. Biophys., 397, 51. (2002).

[13] A. Allouch, V. Roubaud, R. Lauricella, J. C. Bouteiller and B. Tuccio, Org. Biomol. Chem., 1, 593 (2003).

[14] E. Finkelstein, G. Rosen and E. Rauckman, J. Am. Chem. Soc., 102,4994 (1980).

[15] G. Rosen, P. Tsai, J. Weaver, S. Porasuphatana, L. Roman, A. Starkov, G. Fiskum and S. Pou, J. Biol. Chem., 227, 40275 (2002)

[16] P. Tsai, K. Ichikawa, C. Mailer, S. Pou, H. Halpern, B. Robinson, R. Nielsen and G. Rosen, J. Org. Chem., 68, 7811 (2003).

[17] C. Fréjaville, H. Karoui, B. Tuccio, F. Le Moigne, M. Culcasi, S. Pietri, R. Lauricella and P. Tordo, J. Med. Chem., 38, 258 (1995).

[18] I. Yamasaki, L. Piette and T. Grover, J. Biol. Chem., 265, 652 (1990). 
[19] A. Keszler, B. Kalyanaraman and N. Hogg, Free Rad. Biol. Med., 35, 1149 (2003).

[20] R. Lauricella, A. Allouch, V. Roubaud, J. C. Bouteiller and B. Tuccio, Org. Biomol. Chem., 2, 1304 (2004).

[21] A. Allouch, V. Roubaud, R. Lauricella, J. C. Bouteiller and B. Tuccio, Org. Biomol. Chem., 3, 2458 (2005).

[22] R. Lauricella, H. Bouteiller and B. Tuccio, Phys. Chem. Chem. Phys., 7, 399 (2005).

[23] D. Behar, G. Czapski, J. Rabani, L. Dorfman, H. Schwarz, J. Phys. Chem., 1970, 74, 3209

[24] V. Roubaud, H. Dozol, C. Rizzi, R. Lauricella, J. C. Bouteiller and B. Tuccio, J. Chem. Soc. Perkin Trans. 2, 958 (2002).

[25] R. Bonnett, R. Brown, V. Clark, I. Sutherland and S. Todd, J. Chem Soc., 2094 (1959).

[26] G. Olive, A. Mercier, F. Le Moigne, A. Rockenbauer and P. Tordo, Free Rad. Biol. Med., 28, 403 (2000).

[27] H. Karoui, J. L. Clément, A. Rockenbauer, D. Siri and P. Tordo, Tetrahedron Lett., 45, 149 (2004).

[28] W. Press, S. Teukolsky, W. Vetterling and B. Flannery. In Numerical Recipes in FORTRAN: the art of scientific computing, $2^{\text {nd }}$ edn., Cambridge University Press, Cambridge (1992).

[29] J. Baxendale, Radiation Res., 1962, 17, 312 (1962).

[30] D. Duling, J. Magn. Reson. Series B, 104, 5181 (1982).

[31] V. Roubaud, S. Sankarapandi, P. Kuppusamy, P. Tordo and J. Zweier, Anal. Biochem., 247, 404 (1997). 
[32] S. Goldstein, G. Rosen, A. Russo and A. Samuni, J. Phys. Chem. A, 108, 6679 (2004). 


\section{Figure Caption}

Figure 1: Formulae of the nitrone spin traps 1-4 studied.

Figure 2: Formulae of $3 \mathrm{CP} 5$, used as internal reference, and of the spin adducts $\mathrm{N}-\mathrm{O}_{2} \mathrm{H}$ 6-9 studied.

Figure 3: EPR signal obtained in a pH 6.2 buffer by generating superoxide with a xanthine/xanthine oxidase system in the presence of TN $3\left(0.03 \mathrm{~mol} \mathrm{dm}^{-3}\right)$ and of 3 CP $5\left(0.610^{-6} \mathrm{~mol} \mathrm{dm}^{-3}\right)$. The three lines of 5 spectrum are marked by downwards arrows. The other lines belong to the spectrum of $\mathrm{TN}^{-} \mathrm{O}_{2} \mathrm{H} 7$. The framed part corresponds to the signal portion recorded to achieve the kinetic curves.

Figure 4: Experimental (full lines) and calculated (dotted lines) kinetic curves indicating the timedependent changes in $\mathrm{TN}-\mathrm{O}_{2} \mathrm{H} \mathbf{8}$ concentration. A) 8 was produced at $\mathrm{pH} 6.2$ by generating superoxide in the presence of: a) $5 \mathrm{mmol} \mathrm{dm}^{-3} \mathbf{3}$, b) $30 \mathrm{mmol} \mathrm{dm}^{-3} \mathbf{3}$, and c) $125 \mathrm{mmol} \mathrm{dm}^{-3} \mathbf{3}$. B) 8 was produced at $\mathrm{pH}$ 9.3 by generating superoxide in the presence of: a) $20 \mathrm{mmol} \mathrm{dm}^{-3} \mathbf{3}$, b) $40 \mathrm{mmol} \mathrm{dm}^{-3} \mathbf{3}$, and c) $125 \mathrm{mmol}$ $\mathrm{dm}^{-3}$ 3. Calculated curves, obtained according to the model described by equations. (5)-(8), led to $\mathrm{k}_{\mathrm{T} a p}$ and $\mathrm{k}_{\mathrm{D}}$ values given in table 2 .

Figure 5: Variation of the apparent rate constant $\mathrm{k}_{\mathrm{Tap}}$ with $\mathrm{pH}$ for DEPO $2(\boldsymbol{\nabla}), \operatorname{EMPO} \mathbf{1}(\bullet), \mathrm{TN} \mathbf{3}(\star)$, and DMPO 4 ( $)$. The curves have been calculated using equation (19) and the rate constant values listed in table 3. Experimental points have been obtained from $\mathrm{k}_{\mathrm{Tap}}$ values listed in table 2. 
Table 1. EPR hyperfine splitting constants for the nitroxides 5-9 in $0.1 \mathrm{~mol} \mathrm{dm}^{-3}$ phosphate buffer ( $\mathrm{pH}$ range: $6.2-9.3$ )

\begin{tabular}{cccc}
\hline & $\mathrm{a}_{\mathrm{N}} / \mathrm{mT}$ & $\mathrm{a}_{\mathrm{H} \beta} / \mathrm{mT}$ & other $/ \mathrm{mT}$ \\
\hline $\mathbf{5}$ & 1.62 & $/$ & $/$ \\
$\mathbf{6}$ & 1.32 & 1.09 & $0.10\left(\mathrm{a}_{\mathrm{H} \gamma}\right)$ \\
$\mathbf{7}$ & 1.26 & 0.99 & $0.12\left(\mathrm{a}_{\mathrm{H} \gamma}\right)$ \\
$\mathbf{8}$ & 1.34 & 0.16 & $4.24\left(\mathrm{a}_{\mathrm{P}}\right)$ \\
$\mathbf{9}$ & 1.43 & 1.17 & $0.12\left(\mathrm{a}_{\mathrm{H} \gamma}\right)$ \\
\hline
\end{tabular}


Table 2. Apparent rate constants for the spin trapping of superoxide by nitrones 1-4 $\left(\mathrm{k}_{\mathrm{Tap}}\right)$ and for the decay of nitrone-superoxide spin adducts $\left(\mathrm{k}_{\mathrm{D}}\right)$ at various $\mathrm{pH}$.

\begin{tabular}{|c|c|c|c|c|}
\hline nitrone & $\mathrm{pH}$ & $\mathrm{k}_{\mathrm{T} a \mathrm{p}} / \mathrm{dm}^{3} \mathrm{~mol}^{-1} \mathrm{~s}^{-1}$ & {$[\mathrm{~N}] / \mathrm{mmol} \mathrm{dm}^{-3}$} & $\mathrm{k}_{\mathrm{D}} / 10^{-3} \mathrm{~s}^{-1}$ \\
\hline \multirow[t]{15}{*}{ EMPO 1} & 6.2 & $101 \pm 8$ & 150 & $0.88 \pm 0.01$ \\
\hline & & & 30 & $0.48 \pm 0.01$ \\
\hline & & & 10 & $0.45 \pm 0.01$ \\
\hline & 7.2 & $10.9 \pm 0.1$ & 200 & $1.25 \pm 0.04$ \\
\hline & & & 30 & $0.65 \pm 0.04$ \\
\hline & & & 10 & $0.60 \pm 0.04$ \\
\hline & 8.0 & $2.02 \pm 0.08$ & 150 & $0.41 \pm 0.01$ \\
\hline & & & 30 & $0.40 \pm 0.01$ \\
\hline & & & 15 & $0.51 \pm 0.01$ \\
\hline & 8.8 & $0.68 \pm 0.05$ & 150 & $2.66 \pm 0.03$ \\
\hline & & & 30 & $3.68 \pm 0.03$ \\
\hline & & & 10 & $3.56 \pm 0.03$ \\
\hline & 9.3 & $0.60 \pm 0.03$ & 150 & $17.89 \pm 0.78$ \\
\hline & & & 30 & $14.11 \pm 0.78$ \\
\hline & & & 10 & $9.38 \pm 0.78$ \\
\hline \multirow[t]{10}{*}{ DEPO 2} & 6.2 & $185 \pm 15$ & 10 & $6.57 \pm 0.29$ \\
\hline & & & 6.5 & $4.41 \pm 0.29$ \\
\hline & 7.2 & $31 \pm 1.3$ & 15 & $2.06 \pm 0.52$ \\
\hline & & & 5 & $1.04 \pm 0.52$ \\
\hline & 8.0 & $3.54 \pm 0.28$ & 10 & $21.28 \pm 0.48$ \\
\hline & & & 6 & $10.60 \pm 0.48$ \\
\hline & 8.8 & $3.18 \pm 0.32$ & 5 & $6.26 \pm 1.35$ \\
\hline & & & 3 & $3.18 \pm 1.35$ \\
\hline & 9.3 & $1.98 \pm 0.11$ & 10 & $15.84 \pm 1.81$ \\
\hline & & & 3 & $10.56 \pm 1.81$ \\
\hline \multirow[t]{15}{*}{ TN 3} & 6.2 & $58.26 \pm 2.67$ & 125 & $2.40 \pm 0.07$ \\
\hline & & & 30 & $1.93 \pm 0.07$ \\
\hline & & & 5 & $1.57 \pm 0.07$ \\
\hline & 7.2 & $8.90 \pm 0.58$ & 140 & $2.70 \pm 0.27$ \\
\hline & & & 72 & $2.60 \pm 0.27$ \\
\hline & & & 5 & $1.90 \pm 0.27$ \\
\hline & 8.0 & $1.56 \pm 0.11$ & 125 & $4.11 \pm 1.0$ \\
\hline & & & 40 & $4.30 \pm 1.0$ \\
\hline & & & 20 & $4.64 \pm 1.0$ \\
\hline & 8.8 & $0.77 \pm 0.09$ & 125 & $5.07 \pm 0.88$ \\
\hline & & & 30 & $3.85 \pm 0.88$ \\
\hline & & & 15 & $2.99 \pm 0.88$ \\
\hline & 9.3 & $0.56 \pm 0.06$ & 125 & $6.59 \pm 0.55$ \\
\hline & & & 40 & $6.10 \pm 0.55$ \\
\hline & & & 20 & $5.49 \pm 0.55$ \\
\hline
\end{tabular}


Table 2 (continued). Apparent rate constants for the spin trapping of superoxide by nitrones 1$4\left(\mathrm{k}_{\mathrm{T} a p}\right)$ and for the decay of nitrone-superoxide spin adducts $\left(\mathrm{k}_{\mathrm{D}}\right)$ at various $\mathrm{pH}$.

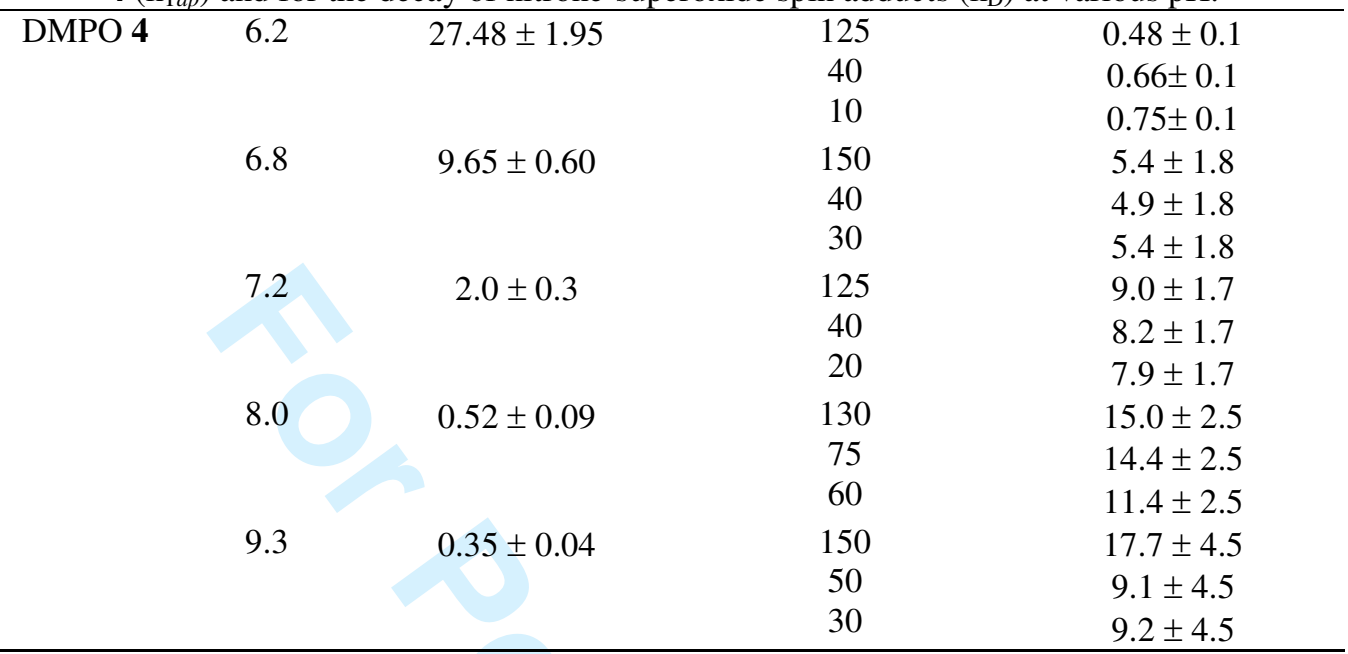


Table 3. Rate constants for the spin trapping of hydroperoxyl radical

\begin{tabular}{cccc}
\multicolumn{4}{c}{$\left(\mathrm{k}_{\mathrm{HO} 2} \cdot\right)$ and of superoxide $\left(\mathrm{k}_{\mathrm{O} 2 \cdot} \cdot\right)$ by nitrones 1-4. } \\
\hline nitrone & $\mathrm{k}_{\mathrm{HO} 2} \cdot / \mathrm{dm}^{3} \mathrm{~mol}^{-1} \mathrm{~s}^{-1}$ & $\mathrm{k}_{\mathrm{O}_{2} \cdot} / \mathrm{dm}^{3} \mathrm{~mol}^{-1} \mathrm{~s}^{-1}$ & $\mathrm{k}_{\mathrm{HO} 2} \cdot / \mathrm{k}_{\mathrm{O}_{2} \cdot{ }^{-}}$ \\
\hline EMPO 1 & $2206 \pm 4$ & $0.41 \pm 0.04$ & $5.3810^{3}$ \\
DEPO 2 & $4015 \pm 30$ & $1.68 \pm 0.65$ & $2.3910^{3}$ \\
TN 3 & $1264 \pm 3$ & $0.57 \pm 0.03$ & $2.2210^{3}$ \\
DMPO 4 & $600 \pm 30$ & $0.34 \pm 0.4$ & $1.7610^{3}$ \\
\hline
\end{tabular}




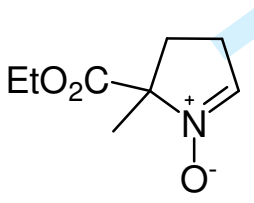

EMPO 1

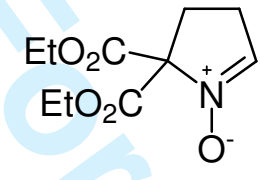

DEPO 2

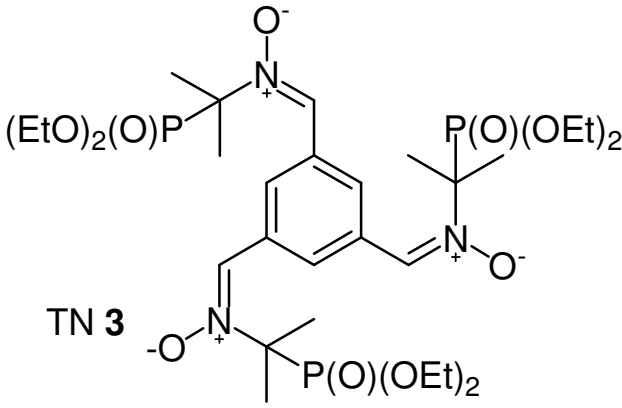

$\overbrace{\substack{N \\ 1 \\ 0^{+}}}$

DMPO 4 
<smiles>CC1(C)CC(C(=O)O)C(C)(C)N1O</smiles>
3CP 5

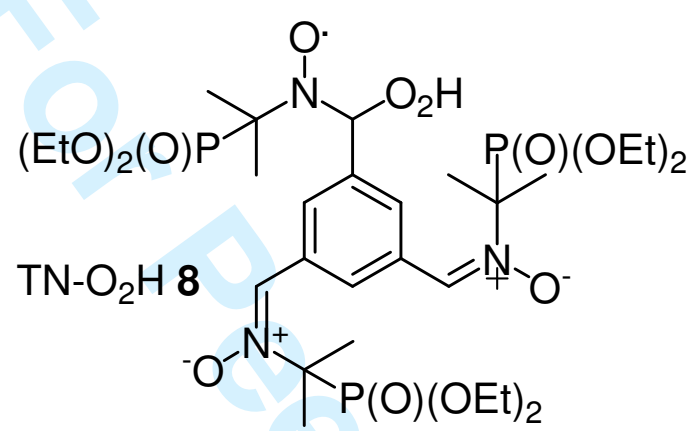<smiles>CCOC(=O)C1(C)CCC(O)N1O</smiles>

EMPO-O ${ }_{2} \mathrm{H} 6$<smiles>CCOC(=O)C1(CO)CCC(O)N1O</smiles>

DEPO- $\mathrm{O}_{2} \mathrm{H} 7$<smiles>COOOO</smiles>

Figure 2

A. Allouch et al. pH Effect on Superoxide Trapping by Nitrones 


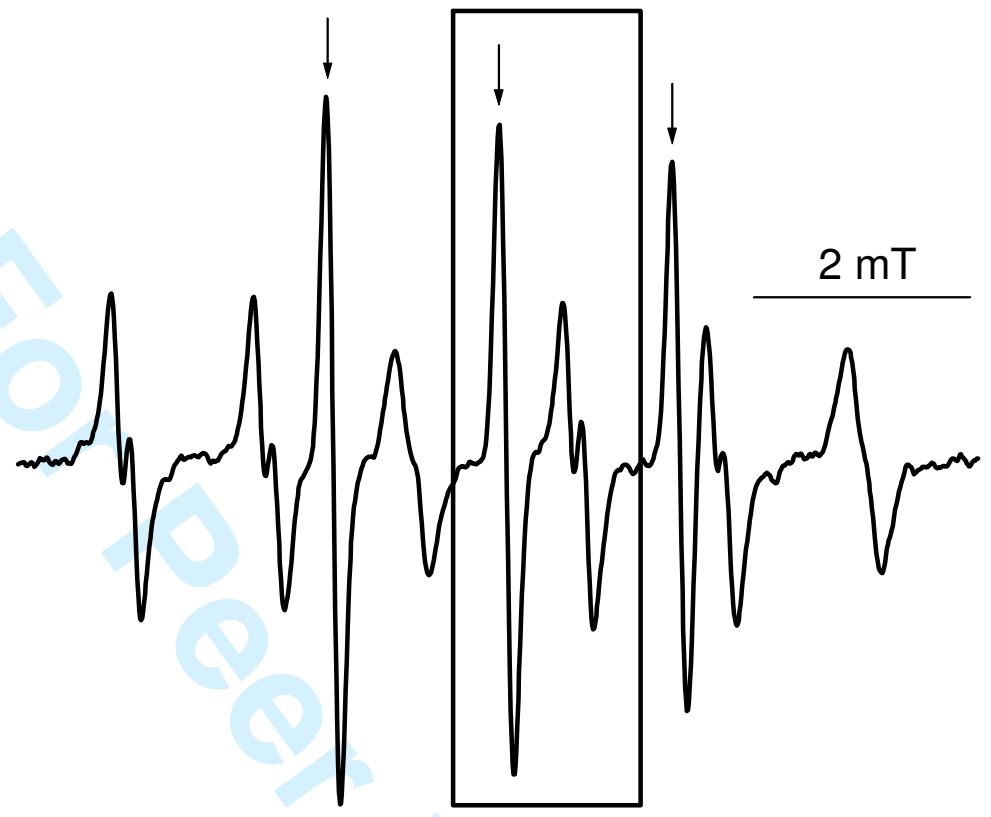

Figure 3

A. Allouch et al. $\quad$ pH Effect on Superoxide Trapping by Nitrones 

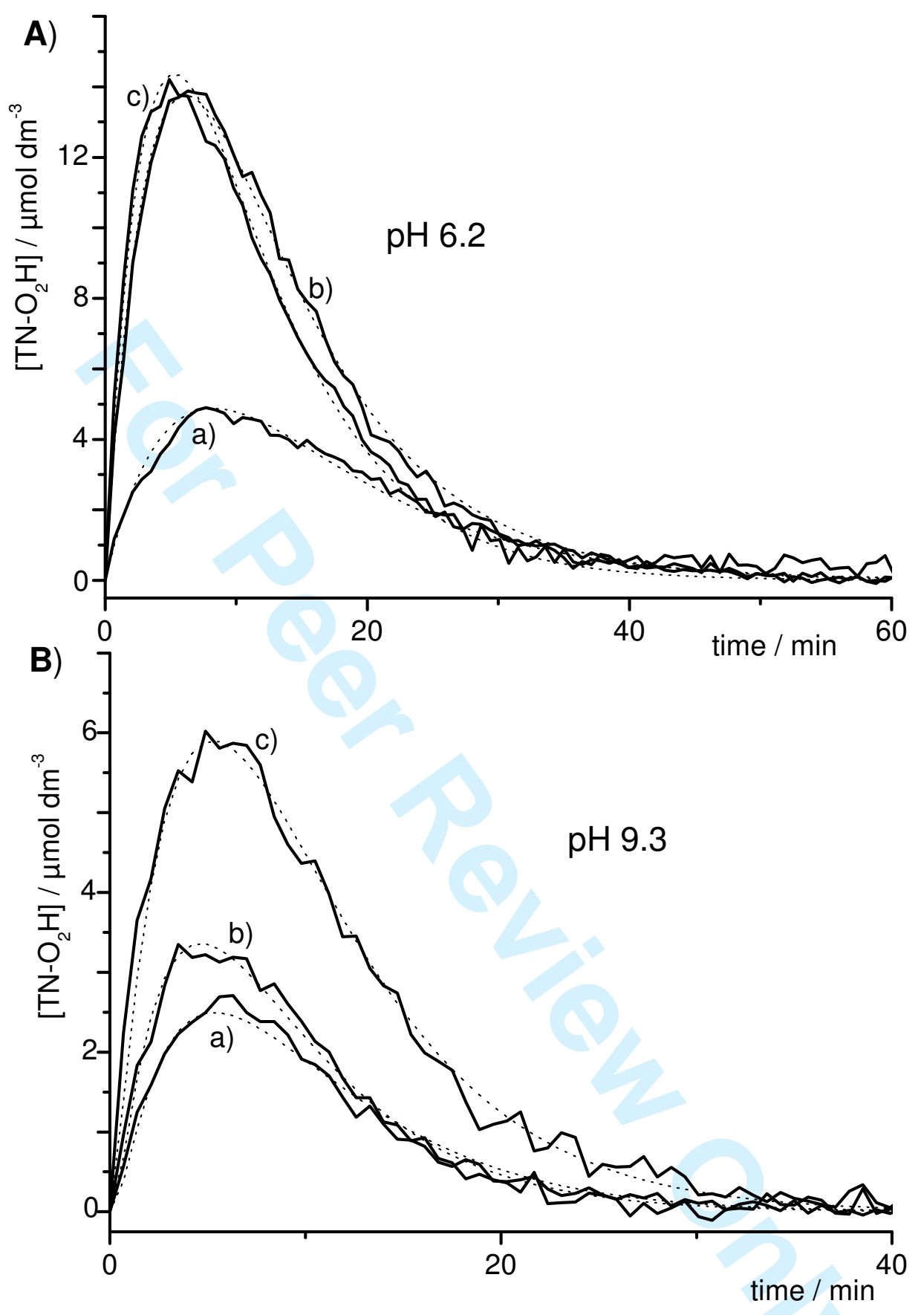

Figure 4 A. Allouch et al. $\quad$ pH Effect on Superoxide Trapping by Nitrones 


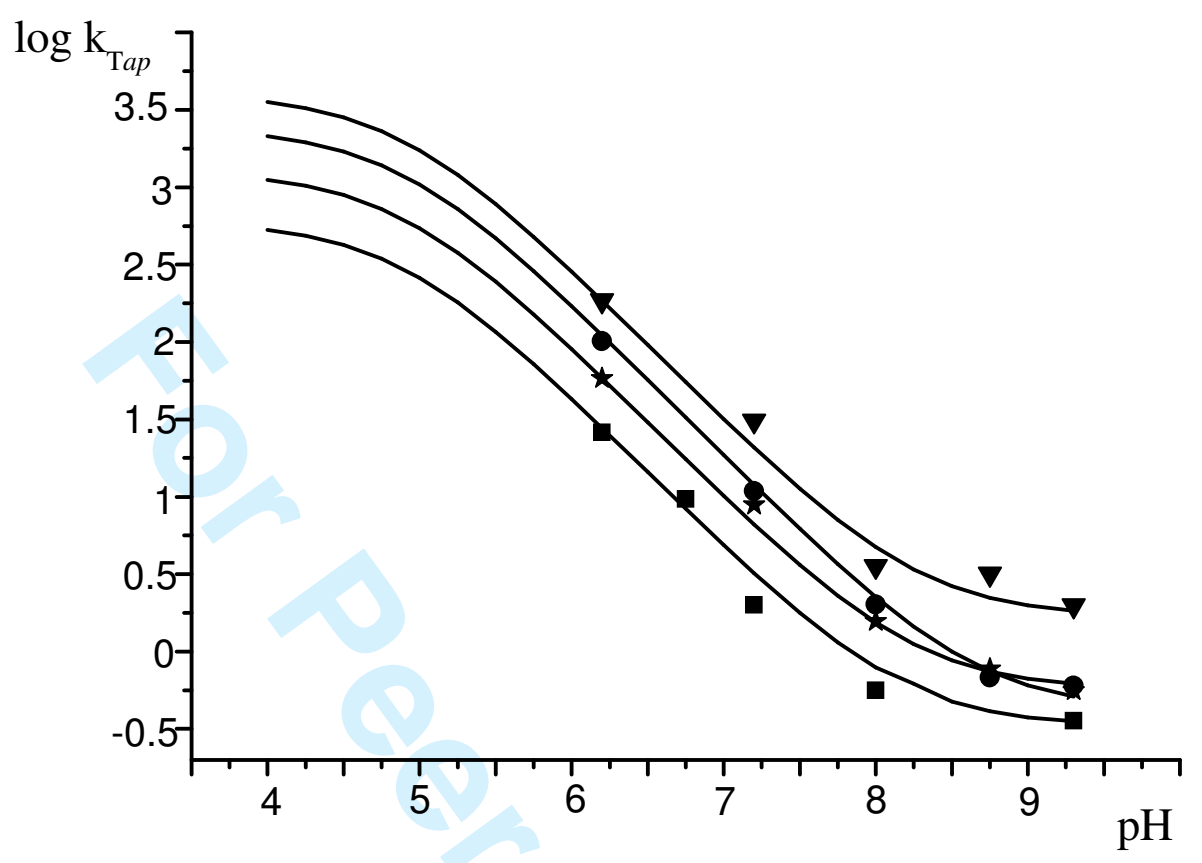

Figure $5 \quad$ A. Allouch et al. $\quad$ H Effect on Superoxide Trapping by Nitrones 